\title{
ÖRTÜLÜ (GIZLI) BOŞLUK VE BU BOŞLUĞUN DOLDURULMASI YÖNTEMİ OLARAK AMACA UYGUN SINIRLAMA (TELEOLOGISCHE REDUKTION)
}

\author{
Yrd.Doç.Dr. Çĭgdem KIRCA*
}

Amaca uygun sımırlama, örtiulï boşlukların doldurulmasında Alman hukukunda öteden beri uygulanan, İsviçre hukukunda ise son zamanlarda doktrinin bir kısmı tarafından kabul edilen bir yöntemdir. Örtülü boşluk ve örtuilü boşlukların doldurulması yöntemi olan amaca uygun sınırlama konusundaki açıklamalarımıza geçmeden önce boşluk kavramı ve türlerine kısaca değinmek istiyoruz

\section{Boşluk Kavramı}

Kanun boşluğu "gerekli kanuni düzenlemenin yapılmamış olması" şeklinde tanımlanır'. Bu tanımdaki "gerekli" kelimesi önem taşır. Zira kanuni bir düzenlemedeki eksiklik, "gerekli bir kanuni düzenlemenin" eksikliği anlamina gelmeyebilir ${ }^{2}$. Bir sorunun düzenlenmesi hukuk dişı bir alanda bulunduğu için (mesela ahlâki veya dini bir konuda olduğu için) gerekmeyebilir veya susma yoluyla kanun koyucu tarafindan negatif olarak düzenlenmiş olabilir ${ }^{3}$. Bütün bu durumlarda kanunda boşluk yoktur ${ }^{4}$.

\footnotetext{
*Ankara Üniversitesi Hukuk Fakültesi Medeni Hukuk Anabilim Dalı Öğretim Üyesi

${ }^{1}$ Bkz., Meier-Hayoz, Art. 1, N. 251; Riemer, § 4, N. 61; Edis, s. 121; İmre, s. 172; Akipek/Akıntürk, s. 124.

2 Bkz., Riemer, § 4, N. 62; Meier-Hayoz, Art. 1, N. 253.

${ }^{3}$ Mesela kanun evliliğin geçersizlik nedenlerini sınırlı olarak saymış, ancak bunlar arasında muvazaaya yer vermemiştir, çünkü kanun koyucu buna imkan tanımak istememektedir.

${ }^{4}$ Bkz., Edis, s. 124 vd.; Akipek/Akıntürk, s. 124, 125; Serozan, § 5, N. 10; Ataay, s. 232 vd.; İmre, s. 173 vd. Kanunda nitelikli bir susmanın mı bulunduğu, yoksa gerekli bir hukuki düzenleme eksikliğinin mi söz konusu olduğu yorum sonucunda belirlenir. Bu durumda hakim, kanunun ne ölçüde sınırlı bir düzenleme yapmak istediğine dikkat etmelidir. Kanunun sustuğu her durumda nitelikli susma söz konusu değildir (Meier-Hayoz, Art.1, N. 255 vd.; Imre, s. 172).
} 
Kanun boşluğu kavramı Canaris tarafından şu şekilde tanımlanmaktadır: "Boşluk, yürürlükte olan hukuk düzeni ölçüsü esas alındığında, pozitif hukukun sınırlan içerisindeki plâna aykın eksikliktir. Hukuk düzeninin bir bütün olarak pozitif bir kuralın varlığını gerektirmesine rağmen (kelimelerden çıkarılabilen anlam çerçevesinde), kanun veya örf ve adet hukuku bunu düzenlememiş ise, boşluk söz konusudur ${ }^{5}$. Kısaca ifade etmek gerekirse boşluk, pozitif hukukun plâna aykırı eksikliğidir ${ }^{6}$.

Bir olayın pozitif bir düzenlemede yer almasının gerekliliği veya başka bir deyişle bunun eksikliğinin plâna aykırılık oluşturması, mevcut hukuk kurallannın (lex lata) bütününün amaca uygun değerlendirilmesi sonucunda tespit edilir7. Bir başka ifade ile plâna aykırı eksiklik, kanundaki bir düzenlemenin onun amacı ve ruhuna bakıldığında eksik ve tamamlanmaya muhtaç olduğu takdirde söz konusudur ${ }^{8}$. Plâna aykırıllğı belirleyen ölçü, pozitif hukukun temelinde yer alan değerler ve amaçlardır. Buna karşıllık yürürlükteki hukukta temelini bulmayan olması gereken hukuk açısından (de lege ferenda) önerilen talepler plâna aykırı eksiklik kavramına dahil edilemez ${ }^{9}$. Dolayısıyla, hukuk politikasına ilişkin talepler doldurulması gereken bir boşluk olarak nitelendirilmez ${ }^{10}$. Bu durumda olması gereken hukuk açısından "hukuk politikası boşlukları" söz konusudur". Mesela, kat mülkiyetine ilişkin kanun çıkarılmadan önce, binaların ayrı bölümleri üzerinde mülkiyet hakkı bir ihtiyaç oluşturmuştu. Ancak bu durumda, pozitif hukukun plânına aykırlık

${ }^{5}$ Canaris, s. 39. Ayrıca bkz., Engisch, s. 180, 181; Rhinow, s. 38, 39, 50 vd..

${ }^{6} \mathrm{Bu}$ boşluk tanımı İsviçre hukuk doktrininde de kabul görmektedir (bkz., Häfelin, FS Nef, s.113vd.). Türk hukukunda ise Öztan/Öztan, boşluğun "plâna aykın bir yetersizliğin” mevcut olması halinde söz konusu olduğunu belirtmektedir (s. 249).

Larenz ise, kanun boşluğu kavramını "kanunun plâna aykırı eksikliği” olarak tanımlamaktadır. Kanun teriminden ise, örf ve adet hukukunu ve kanunlann tümünü anladığını belirtmektedir (Larenz, Methodenlehre, s. 370).

7 Kramer, Methodenlehre, s. 138.

${ }^{8}$ Haefelin, FS Nef, s. 113.

${ }^{9}$ Kramer, Methodenlehre, s. 138; Canaris, s. 33, 34; Engisch, s. 181; Öztan/Öztan, s. 254, 255. Larenz, temelini kanunda bulmamasına rağmen hukuk düzeninin tamamı esas alındığında, Anayasadaki prensipler de dikkate alınarak bazı istisnai durumlarda hakimin hukuk yaratabileceğini kabul etmekte ve buna kanunu aşan hukuk yaratma (Gesetzesübersteigende Rechtfortbildung)) olarak nitelendirmektedir. Burada kanundaki düzenlemelerin dışında (exra legem), ancak bütün hukuk düzeninin ve onun temelinde yatan ilkelerin kapsamı içerisinde (intra ius) gerçekleşen bir hukuk yaratma söz konusudur (Methodenlehre, s. 414). Başka bir deyişle kanunda plâna aykırı bir eksiklik bulunmamakla birlikte, hukuk duizeninin tamamı esas alındı̆̆ında bir düzenlemenin yapılmasının gerektiği ortaya çıkmaktadır.

${ }^{10}$ Kramer, Methodenlehre, s. 138; Canaris, s. 33, 34; Öztan/Öztan, s. 254, 255.

${ }^{11}$ Olması gereken hukukta boşluklar, "kanunun eksikliği" olarak ifade edilmektedir (Edis, s. 128; İmre, s. 163; Öztan/Öztan, s. 254, 255. ). 
söz konusu olmadığından kanun boşluğu yoktu ve dolayısıyla hakimin müdahale yetkisi bulunmamaktayd ${ }^{12}$.

\section{Boşluk Türleri}

Boşluk türleri çeşitli açılardan sınıflandırmalara tabi tutulmuştur. $\mathrm{Bu}$ sinıflandırmanın başında olan hukukta ve olması gereken hukukta boşluklar şeklinde yapılan ayırım gelir ${ }^{13}$. Yukarıda da belirtildiği gibi aslında olması gereken hukukta bulunan boşluklar, hukuk politikasının bir sorunu olup, MK 1 anlaminda hakimin doldurma yetkisi bulunan boşluklar değildir ${ }^{14}$. Nitekim bu sebeple boşluk kavramı "plâna aykırı eksiklik" olarak tanımlanmaktadır. Eğer söz konusu eksiklik pozitif hukukun temelinde yatan bir ilkeye dayanmiyor, tamamen bunun dişında olması gereken hukuk alanında yer alıyorsa, işte bu durumda boşluk "hukuk politikası boşlukları" (rechtspolitische Lücken) veya olması gereken hukuk açısından boşluk (Lücke de lege ferenda) olarak nitelendirilir. Bunların doldurulması hakimin değil, kanun koyucunun yetkisi içerisindedir ${ }^{15}$.

Olan hukukta boşluklar ise, üçe ayralarak incelenmektedir: Kural içi boşluk, açık boşluk, örtülü (gizli) boşluk.

\section{A. Kural içi boşluk}

Kural içi (kanun içi) boşluk, kanunun sımırlan içerisinde ele alınan ve çözümlenmeye çalışılan boşluklardır. Bu durumda şekli olarak bakıldığında kanunda düzenlemeler bulunmaktadır ${ }^{16}$. Ancak bu düzenlemeler genel norm niteliğinde olup, hakimin takdir yetkisine atıfta bulunur ${ }^{17}$. Kural içi

\footnotetext{
${ }^{12}$ Bkz., Larenz, Methodenlehre, s. 373. Engisch'e göre pozitif hukukun plânına aykınlık tespit edilirken, objektif yorum metodu kullanılmalı, kanun koyucunun kanunu yaparken sahip olduğu değerler ve düşünceler değil, günümüzde geçerli olan değerler ve dünya görüşü esas alınmalıdır (bkz ., s. 184, 185).

${ }^{13}$ Bkz., Kramer, Methodenlehre, s. 139. Alman hukukunda Larenz bu ayırımı kanun dahilinde ve kanunu aşan hukuk yaratma (gesetzesimmanente und gesetzesübersteigende Rechtsfortbildung) olarak ifade etmektedir (bkz ., Larenz, Methodenlehre, s. 413 vd.).

14 "Kanunun eksikliği" olarak ifade edilen bu boşluklar için bkz ., Edis, s. 128; İmre, s. 163; Öztan/Öztan, s. 254, 255.

15 Kramer, Methodenlehre, s. 139.

${ }^{16} \mathrm{Bu}$ sebeple kural içi boşlukların kanun boşluğu olarak nitelendirilip nitelendirilmeyeceği tartışmalıdır (bkz., Canaris, s. 26 vd., 130). Bu tartışmalara girmek konumuzun kapsamını aşacağından, hakim görüşü esas alarak sadece kural içi boşlukların bir boşluk türü olduğunu belirtmekle yetiniyoruz.

${ }^{17}$ Bkz., Meier-Hayoz, Art. 1, N. 262 vd.; Edis, s. 132; Riemer, § 4, N. 70 vd.; Kramer, Methodenlehre, s. 140; Rhinow, s. 52 vd.; Serozan, § 5, N. 23; İmre, s. 175.
} 
boşluklarda haklı (muhik) sebep, halin icabı gibi geniş ve esnek çerçeveli kavramlara yer verilmiş olup, hakim takdir yetkisine göre hakkaniyet kuralını esas ala rak (MK 4) bu kavramlanı somutlaştırır ${ }^{18}$.

\section{B. Açık Boşluk}

Açık boşluk ${ }^{19}$, kanunun belli bir soruna plâna aykırı olarak çözüm getirmemesi durumunda ortaya çıkar ${ }^{20}$. Başka bir deyişle açı boşluk, düzenlemenin amacina ve temel düşüncelerine göre cevap verilmesi gereken bir soruna kanunun cevap vermemesidir ${ }^{21}$. Somut uyuşmazlığa kanunun ne lafżna, ne de onun yorumu ile elde edilen içeriğine göre olumlu veya olumsuz herhangi bir çözüm getiren kurala rastlanılmazsa, bu durumda açık boşluk vardurien.

Açık boşluk, özellikle "teknik boşluk" 23 olarak ifade edilen durumlarda ortaya çıkar. Teknik boşluk kanunun devlete belli bir görev verdiği, ancak bunu yerine getirecek yetkili devlet organını veya gerekli usulü belirlemediği takdirde söz konusu olur ${ }^{24}$.

Açık boşluklara genellikle şu örnek verilmektedir ${ }^{25}$ : MK 454'de terekesi borca batık miras bırakanın cenaze giderlerinin kimler tarafından karşılanacağı belirtilmemiştir. Burada nitelikli bir suskunluk değil, plâna aykırı bir eksiklik bulunmaktadır. Bu boşluk MK 315, 316 kuraları kıyasen uygulanarak doldurulur. Dolayısıyla bu giderlerin kanunda öngörülmüş nafaka borçlulan tarafından ödenmesi kuralı yaratılmış olur. Zira yardım nafakası ödemekle yükümlü yakınların, o kişinin cenaze masraflarını öncelikle karşılaması bir mantık kuralı gereğidir ${ }^{26}$.

\footnotetext{
${ }^{18}$ Serozan, § 5, N. 23; İmre, s. 175.

${ }^{19}$ Açık, esas, extern, dış, hukuk sistematiğinden doğan, mantıksal, dışarıdan görülebilen boşluk olarak da adlandırlmaktadır (bkz., Meier-Hayoz, Art. 1, N. 274).

${ }^{20}$ Bkz., Kramer, Methodenlehre, s. 141.

${ }^{21}$ Zitelmann, s. 27; Meier-Hayoz, Art. 1, N. 271, 274; Riemer, § 4, N. 81; Caroni, s. 150; Öztan/Öztan, s. 250.

${ }^{22}$ Serozan, $\$ 5$, N. 9, 10; Imre, s. 176.

${ }^{23}$ Canaris teknik boşluk terimi yerine, "fonksiyon boşluğu" veya "hukuktan kaçınma boşluğu" terimlerini kullanmaktadır (s. 151).

${ }^{24}$ Meier-Hayoz, Art. 1, N. 274.

${ }^{25}$ Serozan, $\$ 5$, N. 10; Edis, s. 134; Akyol, s. 270.

${ }^{26}$ Serozan, $\$ 5$, N. 10.
} 
Açık boşluk, aynı zamanda kanundaki düzenlemelerinin birbirine açıça aykın olması durumunda söz konusu olur ${ }^{27}$. Tamamen birbirine zit normlar kendilerini ortadan kaldırır ve bu durumda "çatışma boşluğu"ndan söz edilir.

\section{C. Örtülï Boşluk}

Türk/İsviçre doktrininde hakim görüş, boşlukları gerçek boşluk- gerçek olmayan boşluk ayırımına tabi tutmakta ve örtülü boşluğu ${ }^{28}$ gerçek olmayan boşluk olarak ifade etmektedir ${ }^{29}$. Meier-Hayoz gerçek olmayan boşluğu ${ }^{30}$ şu şekilde tanımlamı̧șr: Kanun koyma politikası, hakim toplumsal anlayış (realizm) ve gerçek hukuk açısından kuralın içeriği yeterli görülmüyor ise gerçek olmayan boşluk vardır. Bu durumda eksik olan veya tam olmayan kural, uygun düzenleme ile tamamlanır ${ }^{31}$. Riemer de benzer şekilde, gerçek olmayan boşluğun, kanunun belli bir sorunun cevabını taşımasına rağmen, bu cevabın somut olayda maddi açıdan tatmin edici olmaması, açıkça haksız olması durumunda söz konusu olduğunu belirtmektedir ${ }^{32}$.

Kramer ise, gerçek olan ve gerçek olmayan boşluk ayırımını reddetmektedir ${ }^{33}$. Yazara göre, gerçek olmayan boşluk terimi başından

${ }^{27}$ Bkz., Kramer, Juristischen Methodenlehre, s. 142, 143; Canaris, s. 65 vd; Bydlinski, s. $463 \mathrm{vd}$.

28 Örtülü boşluk terimi yerine çok çeşitli bir terminoloji kullanılmaktadır: Hukuk politikası açısından, gerçek olmayan, gizli, iç, eleştirisel, karar verici, doğruluk, değerlendirme, istisnai boşluk gibi (bkz ., Meier-Hayoz, Art. 1, N. 275; Öztan/Öztan, s. 251).

${ }^{29}$ Bkz., Meier-Hayoz, Art. 1, N 271 vd., 275; Riemer, § 4, N. 82, 83; Caroni, s. 150; Akyol, s. 270-272. Edis, örtülü boşlukları gerçek olmayan boşluklann bir alt türü olarak kabul etmektedir. Kanundaki çözüm tarzı beğenilmiyorsa, ihtiyaçlara uygun veya tatmin edici değilse "gerçek olmayan boşluk" vardır. Yazara göre, gerçek olmayan boşluk, kanunun çözüm tarzının beğenilmemesini, tatmin edici olmamasını, bir başka deyişle kanunun eksikliğini kapsadığı gibi, örtülü boşlukları da kapsar. Örtiilü boşluklar ise, kanunda bir hüküm bulunmakla beraber kuralın sözü ile özünün bağdaştınlmasının mümkün olmadığı durumlarda ortaya çıkar. Bir kural aynı değerde ve güçte bir başka kural ile çatışmakta ise veya bir kuralın yorumundan elde edilen anlamda uygulanmasının doğruluk ve güven ilkesi ile bağdaşmaması nedeniyle hakkın kötuiye kullanılması olarak nitelendirilebiliyorsa "örtülü kanun boşluğu” söz konusudur (s. 133, 134). Hatemi'ye göre ise, örtülü boşluk gerçek olmayan boşluğun değil, gerçek boşluğun bir alt kavramidir (s. 78).

${ }^{30}$ Yazar, bu boşluğu "hukuk politikası açısından boşluk" olarak ifade etmektedir (bkz., MeierHayoz, Art. 1, N. 294, 295).

${ }^{31}$ Meier-Hayoz, Art. 1, N. 275-278.

32 Riemer, § 4, N. 82.

${ }^{33}$ Kramer, Teleologische Reduktion, s. 71, 72. Bkz., Dürr, Art.1, N. 322. Haefelin gerçek ve gerçek olmayan boşluk ayrımından kaçınılması, onun yerine sadece hakinin hukuk yaratması ile doldurulabile cek kanun boşluğun teriminin kullanılması gerektiği görusşündedir (FS Nef, s. 99, 100). 
itibaren talihsiz olup, bir taraftan gerçek anlamını ifade etmekten yoksundur, diğer taraftan "gerçek boşluk" karşısında daha az değerli ve şüpheli olduğu konusunda yanlış bir izlenim taşır. Meier-Hayoz da daha sonra biraz evvel açıkladığımız düşüncesinden ayrılarak bu görüşü desteklemiştir ${ }^{34}$. MeierHayoz, boşluk doldurmanın bir taraftan kanunun yorumlanarak uygulanmasindan, diğer taraftan, kanunun düzeltilmesinden ayn olduğunu, bu farklılı̆̆ın ortaya konulması gerektiğini belirtmektedir ${ }^{35}$. Gerçek olmayan boşluk kavramı bu üç alanın birbiriyle karışmasına neden olmaktadır. Bu nedenle gerçek olmayan boşluk kavramından vazgeçilmelidir. Biz de bu görüşe katılıyoruz ve örtülü boşluk konusunda şu tanımı benimsiyoruz:

Örtülï (gizli veya istisnai) boşluk, kanunun çok geniş kapsaml, gerekli istisnalara yer vermemiş olan kelime anlamının, kanunun amacı ve negatif eşitlik ilkesi (eşit olmayana eşit şekilde davranmama) esas alındığında bir sınırlandırmayı gerektirmesi durumunda ortaya çıkan boşluktur ${ }^{36}$. Örtülü boşluk durumunda, kanunda somut olaya uygulanması mümkün bir kuralın açıkça düzenlenmiş olduğu görülmektedir, ancak kanunun amacı ve ruhu esas alındığında, düzenleme somut olaya uygun değildir. Çünkü kanun, söz konusu olayların değerlendirmesinde önem taşıyan bazı özellikleri dikkate almamıștır. Kanunun lafzı çok geniş olup, tüm daraltıcı yorum çabalarına rağmen, somut olayın istisnai özelliklerine uymamakta, adalete aykırı sonuçlar doğurmaktadır. Bu durumda boşluk görünürde bir kanun hükmü olmasına rağmen, kanunun amacı ve negatif eşitlik ilkesi esas alındığında düzenlenmesi

\footnotetext{
${ }^{34}$ Yazar, emekliliği nedeniyle kendi adına yapılan sempozyumun kapanış konuşmasında, tebliğ sunanlardan "Ernst Kramer'in ikna edici açıklamalanı bu talihsiz görünümden tamamıla ve bütünüyle vazgeçme konusundaki isteğimi güçlendirmiştir" ifadesini kullanmıştır (MeierHayoz, Schlusswort, s. 90, 91).

${ }^{35}$ Yazara göre kanunda bir yetersizlik anlamında boşluğun var olmadı̆̆ durumlarda gerçek olmayan boşluktan da söz edilemez. Ay rıca, kanunun geniş lafzının yorum yoluyla daraltılması durumunda, kanunun yorumu söz konusudur, yoksa boşluk doldurma alanında bulunulmaz. Diğer taraftan amaca uygun sınırlama ile doldurulması gereken bir boşluk tespit edildiğinde, örtülü (gizli) veya istisnai boşluk vardır. Bu boşluk ise, açık boşluk gibi gerçek boşluktur. Dolayısıyla gerçek olmayan boşluktan bahsedilmesi isabetsizdir. Son olarak yorum yoluyla tespit edilen düzenleme başlangıcından itibaren eksik veya yanlış, ya da zaman içinde şuipheli hale gelmişse, bu durumda hakimin kanunu düzeltme yetkisi kural olarak bulunmamaktadır. Ancak sadece aşikar haksızlık durumlannda hakkın kötüye kullanılması yasağına başvurularak normun düzeltilmesi yapilabilir (Meier-Hayoz, Schlusswort, s. 91).

${ }^{36}$ Bkz., Kramer, Teleologische Reduktion, s. 71 72; Larenz, Methodenlehre, s. 391, 392; Larenz/ Canaris, s. 198; Bydlinski, s. 480; Serozan, § 5, N. 9, 14; Öztan/Öztan, s. 251; Ataay, 238 vd., 241; Hatemi, s. 76. Kramer, örtülü veya gizli boşluk terimi yerine, istisnai boşluk terimini kullanmaktadır, (Juristischen Methodenlehre, s. 142, 143). Imre'ye göre, "geniş kapsamlı bir kanun kuralı bulunduğu ve buna ait gerekli sınırlamanın bu kural veya kanunun diğer bir kuralı tarafından yapılmamış olması halinde kanun boşluğu gizli ve örtüluidüir... Örtülü (gizli) boşluklar MK. mad. 1, fik. 2'nin uygulama alanına girer" (s. 176).
} 
gereken bir nokta olarak ortaya çıkan, bir sınırlama eksikliğinden doğan boşluktur ${ }^{37}$. Illk bakışta bir düzenleme varmış gibi görünmesinden dolayı bu boşluk örtülüidür (gizlidir) ${ }^{38}$.

\section{Ç. Diğer Boşluk Türleri}

Yukanda açıklanan boşluk türleri dışında bilinçli boşluk- bilinçli olmayan boşluk; başlangıçtaki boşluk- sonraki boşluk şeklinde ayrilan boşluk türleri de bulunmaktadir ${ }^{39}$.

\section{Boşlukların Doldurulması}

\section{A. Açık boşlukların doldurulması}

Hakim, somut olaya uygulanacak kuralı tespit etmek için önce yo-rum yoluna başvurur. Ancak yorum sonucunda olaya uygulanabilecek yazilı bir hukuk kuralının veya örf ve adet kuralının bulunmadığı so-nucuna varırsa hakim, MK 1/l'e göre kanun koyucu gibi kural koyarak boşlukları doldurur.

Açık boşlukların doldurulmasında en önemli araç kıyastır. MK 1'de, kanunda boşluk bulunduğu durumlarda kıyasa başvurulması gerektiği, diğer hukuk sistemlerinin ${ }^{40}$ aksine açıkça öngörülmemiştir. Kıyasa başvurulması durumunda kanunda boşluk bulunmadığı, kıyasın kanunun yorumuna dahil olduğu şeklindeki görüş, bugün hakim doktrin tarafından kabul edilmemektedir $^{41}$.

\section{B. Örtülü Boşlukların Doldurulması}

\section{Genel Olarak}

İsviçre- Türk hukukunda bugüne kadar hakim olan doktrin, örtülü boşlukları gerçek olmayan boşluk olarak nitelendirmiş ve normun somut olaya

${ }^{37}$ Bkz., Larenz, 391; Larenz/Canaris, s. 198; Bydlinski, s. 480; Serozan, § 5, N. 9, 14; Öztan/Öztan, s. 251; Ataay, 238 vd., 241; Hatemi, s. 76, 78.

${ }^{38}$ Larenz/Canaris, s. 198.

${ }^{39}$ Çalışmamızın amacı ve kapsamı bu ayırımlara ayrıntısıyla değinmeyi gerektirmemektedir. Bu konuda bkz., Edis, s. 135, 136; Dürr, Art. 1, N. 336 vd.

${ }^{40}$ Bkz., Avusturya Medeni Kanunu $\S 7$, İtalyan Medeni Kanunu m. 12/II, İspanya Medeni Kanunu 4/I, Portekiz Medeni Kanunu 10/I-II.

${ }^{41}$ Bkz., Meier-Hayoz, Art. 1, N. 346 vd.; Zeller, s. 485; Larenz/Canaris, s. 202 vd.; Canaris, s. 71 vd.; Bydlinsky, s. 467. 
uygulanmasının hakkın kötüye kullanılması oluşturduğu istisnai durumlarda, çok büyük bir dikkatle düzeltilebileceğini kabul etmiştir ${ }^{42}$. Nitekim MeierHayoz'a ${ }^{43}$ göre, "kanun koyucu belli durumlar hakkında açıkça yanılmış veya kanunun konulmasından sonraki hukuki ilişkiler ve şartlar önemli ölçiide değişmiş ise ve bunun sonucunda hukuk kuralı kanun koyma politikası, ahlâk ve realite açısından tatmin edici nitelikte değilse, bu kuralın uygulanması normun kötüye kullanılması oluşturur- ve mevcut normun uygulanması hakkın kötüye kullanılması olarak ortaya çıkıyorsa özel hukukumuzda hukuk politikası boşluğu (örtülü boşluk) bulunmaktadır”.

Oysa daha önce belirttiğimiz gibi, örtülü boşluklar da hakimin hukuk yaratma yetkisinin bulunduğu gerçek boşluktur ve bu boşlukların amaca uygun sinırlandırma yoluyla doldurulması gerektiği savunulmaktadır. Bu görüş Alman hukukunda uzun zamandan beri kabul edilen, İsviçre hukukunda da son zamanlarda savunulan bir görüştür. Bizim de katıldığımız bu görüşü ve gerekçelerini ayn bir başlık altında açılamak istiyoruz:

\section{2. Örtülü Boşlukların Amaca Uygun Sınırlama Yoluyla Doldurulması}

Amaca uygun sinurlama (teleologische Reduktion veya Restriktion), kanunun amacı ile karşılaştırıldığında çok geniş kapsamlı, farklılaştırılmamış kelime anlamının, yorum yoluyla elde edilmiş düzenleme amacının (ratio legis'in) gerektirdiği uygulama alanına indirgenmesi veya bu alanla sınırlandırılmasıdır ${ }^{44}$. Böylece normun uygulanma alanı kimi zaman sinırlı

\footnotetext{
${ }^{42}$ Bkz., Meier-Hayoz, Art. 1, N. 296; Merz, Art. 2, N. 25; Edis, s. 133, 134; Serozan, § 5 , N. 21, s. 97; Akyol, 270-272; Akipek/Akıntürk, s. 126. BGE 120 III 131, 134; 123 III 445. Dürr, kanunun amacı ile lafzının çatıştığı durumlarda, lafızdan ayrılmanın sadece MK 2/II'nin şartlarının gerçekleştiği takdirde mümkün olacağı görüşünii kabul etmemektedir. Yazara göre, kanunun lafzı hakimin hukuk yaratma faaliyetini sınırlandıramaz ve özellikle kanunun lafzı jlk planda hukuki soruna bir cevap veriyormuş gibi görünse, bir başka deyişle eksiklik değil, fazlalık olsa bile hakimin hukuk yaratma faaliy etini sınulandımamalıdır (Art.1, N. 375, 374).

İsviçre kamu hukuku uygulaması, önceleri gerçek olmayan boşlukların hakkın kötiuye kullanılması yasağı ile giderilebileceğini kabul ederken, daha sonra, düzenlemenin gerçek anlamının gerektirdiği şekilde isabetli sebeplerin (triftige Gründe) varı̆̆g durumunda açık lafızdan ayrilınabileceğini kabul etmiştir (BGE 87 I 16; $99 \mathrm{Ib} 505,508 ; 113$ 1a 12, 14; 111 la 297).

${ }^{43}$ Meier-Hayoz, Art. 1, N. 296.

${ }^{44}$ Bkz., Larenz, s. 391; Larenz/Canaris, s. 210, 211; Kramer, Teleologische Reduktion, s. 65, 66: Dürr. Art. 1, N. 104; Zippelius, s. 59, 60. Bir normun ruhunun kontrolü sonucunda hukuku oluşturan amaç, değer, mantık ve gelişime göre, kullanılan lafzın kelimne anlamından dar bir anlam ortaya çıkıyorsa, sınırlama (Reduktion) söz konusudur. Bir kanun maksadından daha fazlasind söyleyemez (Fikentscher, s. 311).
} 
normun eklenmesi, kimi zaman da kelime anlamının geniş olanı yerine dar olanının kabul edilmesi ile daraltılmaktadır ${ }^{45}$. Amaca uygun smırlama (amaç böyle gerektir-diğinden) normun tüm uygulama alanı için sınırlanması veya (düzenle-menin tamamlanmasın için) istisnai bir durumun eklenmesi ile yapilır.

Örtuilü boşlukların amaca uygun sınırlama ile doldurulmasını kabul eden görüş ${ }^{46}$ öncelikle burada gerçek bir boşluk bulunduğundan hareket $\operatorname{eder}^{47} . \mathrm{Bu}$ görüşe göre, açık boşluklarla örtülü boşluk arasında nitelik açısından bir fark yoktur. Kanun koyucunun bir sorunu önceden görmediği için düzenlememesi ile, olayı ve onun istisnai niteliğini görmediği için geniş kapsamlı bir norm ile düzenlemesi arasında bir fark bulunmamaktadır ${ }^{48}$. Nasıl açı boşluklarda kanunun amacı esas alındığında kelimelerin anlamı çok dar, eksik tutulmuşsa, örtülü boşluklarda mantıklı amacın ötesinde, amaca uygun değerlendirildiğinde olaylara uymayacak şekilde geniş tutulmuştur ${ }^{49}$. Gerçek boşluklarda kıyasa esas alınan normun uygulanması, bu normun kelime anlamı somut olaya uygun olmasa da kabul edilir. Örtülü boşluklarda ise, olaya açıkça uygun görünen normun uygulanması reddedilmektedir. Her iki durumda da esas alınan kanunun amacidır (ratio legis).

Fikentscher'e göre amaç, sınırlamaya yol açan unsurlardan bir tanesidir. Dolayısıyla amaca uygun sınırlama (teleologische Reduktion) kavramı çok dardır. Amaç dışında, değerleri kapsayan, mantıksal ve hukukun gelişimini ölçü alan sınırlama durumlan da söz konusudur. Bu nedenle sadece sinurlama (Reduktion) terimi kullanılmalıdır (s. 311, dn. 66).

45 Larenz, s. 391; Larenz/Canaris, s. 211 ; Canaris, s. 189.

${ }^{46}$ Bkz., Kramer, Teleologische Reduktion, s. 71 vd;; Kramer, Methodenlehre, s. 162, 163; Honsell, FS Mayer-Maly, s. 380 vd.; Caroni, s. 151, 152; Larenz/Canaris, s. 198, 210, 211; Ziegler, s. 15, dn. 20. BGE 121 III 219, 226.

${ }^{47}$ Bkz., Kramer, Teleologische Reduktion, s. 71 vd;; Kramer, Methodenlehre, s. 162, 163; Meier-Hayoz, Schlusswort, s. 91; Ziegler, s. 15, dn. 20. İmre örtülü boşlukların MK 1/II'nin uygulama alanına girdiğini kabul etmektedir (s. 176). Karş., Brandenburg, 60 vd., 63, 64. Schneider örtülü boşluk kavramını geniş anlamda gerçek boşluğun bir alt türü olarak nitelendirmekte ve amaca uygun sinılama ile doldurulmasını kabul etmektedir. Ancak, gerçek olmayan boşluk kavramını saklı tutulması ve kanunun istisnai olarak düzeltilmesi gerektiği durumlarda bu terimin kullanılması önerisinde bulunmaktadır (ZBJV 1996, s. 213). Hatemi örtülü boşlukları gerçek boşlukların bir türü (alt kavramı) olarak kabul etmektedir "Açık boşlukta karşılaştı̆̆ımız vakıalar bütünü için hiçbir kural yok iken, örtülü boşlukta genel bir kural vardır da kayıtlanması gerekmektedir. Yazar, mantıken kabul edilebilir ve kuralın kanundaki varlığını açıklayabilir bir "ratio legis"i bulunmayan kanun kurallan için gerçek olmayan boşluktan söz edilebileceğini belirtmekte ve bu boşluklann önce MK 2/II kuralı ile bertaraf edileceğini, daha sonra bu boşlukların doldurulması için harekete geçileceğini savunmaktadır ( s. 78).

${ }^{48}$ Honsell, FS Mayer-Maly, s. 383.

${ }^{49}$ Kramer, Teleologische Reduktion, s. 73. 
Açık boşluklarda hakimin kıyas yapması pozitif hukuka uygun kabul edilirken, örtuilï boşlukların doldurulmasının normun uygulanmasının açıkça hakkın kötüye kullanılması teşkil ettiği durumlarla sinırlandırılmaktadır. Oysa amaçsal yorum metodu temelinde her iki boşluğun doldurulması pozitif hukuk açısından hukuka uygundur ${ }^{50}$. Açık boşlukların kıyas yoluyla doldurulması, adaletin bir gereği olan eşitlik ilkesi, yani değerlendirme açısından benzer olana benzer şekilde davranma emri dolayısıyladır. Amaca uygun sınırlandırma ise, adaletin bir gereği olan negatif eşitlik, yani eşit olmayana eşit olmayan bir şekilde davranma ilkesinin bir sonucudur ${ }^{51}$. Bu da değerlendirme ile ortaya çıkan farklılıkları göz önünde bulundurmayı gerektirir. Negatif eşitlik ilkesi, ya sinırlanması gereken normun amacından veya bir diğer normun başka şekilde gerçekleşmesi mümkün olmayan öncelikli amacından, ya da "eşyanın tabiatından" veya belli bir olay grubu için öncelik taşıyan kanunda yer bulan bir ilke dolayısıyla ortaya çıkar ${ }^{52}$.

Amaca uygun sınırlandırma yoluyla örtülü boşlukların doldurulmasını reddeden görüş, böyle bir imkânın IMK 1 (MK 1)'de yer almadığı gerekçesini ileri sürmüştüir ${ }^{53}$. Bu görüş, amacı esas alındığında kanunun kesinlikle düzenlemek istemediği olayları, geniş kelime anlamı dolayısıyla kapsadığı durumlarda boşluk bulunmadığını kabul etmektedir. Nitekim Zitelmann'a göre, kanunun tanımadığı bir talebin tanınmaması, kanunun yapmadığı bir istisnanin kabul edilmemesi gerekir" ${ }^{54}$.Zitellman bu hususta "negatif genel bir ilke" kabul etmiştir. Bu ilke uyarınca kanunun özel olarak düzenlediği durumlar dışındaki "tüm fiiller cezasız ve tazmin edilmeksizin kalır". Oysa bu ilke ceza hukukunda geçerli iken, özel hukukta geçerli değildir. Ceza hukukuna göre, bir fiil yapılmadan önce kanunda cezalandırılacağı belirtilmişse, ancak o takdirde cezalandırılabilir. Özel hukukta ve diğer hukuk alanlarında ise, "genel negatif ilke" dolayısıyla, kanunda açıkça belirtilmemiş davranışların herhangi bir sonuç doğurmayacağı kabul edilemez ${ }^{55}$. Kanunlar

\footnotetext{
${ }^{50}$ Kramer, Teleologische Reduktion, s. 73. Larenz/Canaris, s. 211. Bu açıdan amaca uygun smırlandırma ile boşluk doldurmada preater legem boşluk doldurma alanında bulunulur. Burada kanunun amacı esas alındığından kanuna aykın (conra verba) değil, kanunun lafzına aykın (conra verba, fakat secundum rationem legis) bir durum söz konusudur (Bkz., Kramer, Methodenlehre, s. 144, 162; Caroni, s. 151- 152).

${ }^{51}$ Larenz/Canaris, s. 211; Canaris, s. 82 vd.

52 Larenz, Methodenlehre, s. 392.

53 "Aslında hakimin açık olsun örtülü olsun boşlukları doldurma yetkisinin mutlaka kanunda yer alan bir kurala dayanması gerekli değildir. MK 1 olmasaydı da açık boşlukların doldurulması gerekirdi. Nitekim Almanya'da boşlukların doldurulması için AMK'de hiçbir dayanak aranmaz. Hakimin boşluk doldurması her şeyden önce Anayasanın, özellikle eşitlik ve hukuk devleti ilkelerinin gereğidir" (bkz., Serozan, § 5, N. 21, s. 96, 97).

${ }^{54}$ Zitelmann, s. 19.

${ }^{55}$ Bkz., Larenz/Canaris, s. 199; Canaris, s. 49, 50, 132, 133; Bydlinski, s. 236 vd., 472.
} 
tamamıla mükemmel değildir ve böyle bir kuralın uygulanması insanlar arasındaki hukuki ilişkilerin karmaşıklığı, sürekli değişmesi ve gelişmesi dolayısıyla uygulanmaya elverişi değildir. Dolayısıyla normun konulma amacının bir düzenlemeyi gerektirmesine rağmen bunun bulunmamasına veya düzenlemenin mevcut olmasına rağmen, kanunun amacının somut olay için gerektirdiği sınırlamanın yapılmamasına göre kanunda açı veya örtülü boşluk ortaya çıkabilir ${ }^{56}$.

İsviçre Medeni Kanunu'nun 1. maddesini hazırlarken Eugen Huber Aristo'nun "Nikomak'ın Ahlâkı" ad adl eserinden etkilenmiştir ${ }^{58}$. Orada ise sadece kıyas ile boşluk doldurma değil, genelleştirme ile ortaya çıkan yanlışlıklar da söz konusuydu. IMK 1, (MK 1)'de kıyas ve amaca uygun sınırlama açıkça düzenlenmemiştir, fakat her ikisi de IMK 1/I, (MK 1, c.1)'in yorumu sonucunda ortaya çkar ve IMK 1/II, (MK 1, c.2)'nin hakime verdiği düzenleme yetkisinin kapsamına girer ${ }^{59}$. Bu itibarla kıyas gibi, amaca uygun sınırlama da geçerli olarak kabul edilmelidir. Dolayısıyla MK 1, c.2, sadece açık boşluklar için değil, örtuilü boşluklar için de geçerlidir. Bu sonuca MK 1 , c.2'nin Fransizca veya İtalyanca metni esas alınarak da varilabilir ${ }^{60}$. Zira bu metinlerde "uygulanabilecek bir normun eksikliği" v1 veya "kanun koyucunun bir durumu daha önce görmemesi" ${ }^{2}$ halinde hukuk yaratılabileceği belirtilmektedir. MK 1/I maddesi, "hakkında kanuni hüküm bulunmayan mes'elede" ifadesini kullanmıştır. Bu durumda aslına uygun tercümenin esas alınması doğru olur. Türk hukukunda da bu düşünceden hareket eden bir görüş, örtiilü boşlukların aynen açık boşluklar gibi MK l'in uygulama alanına girmesinin, "uygulanabilir bir kanun hükmünün bulunmaması", "doğru dürüst uygulanabilir bir hüküm bulunmaması" şeklinde anlaşılırsa mümkün olacağını kabul etmektedir ${ }^{63}$.

\footnotetext{
${ }^{56}$ Larenz/Canaris, s. 199.

57 Aristo'nun "Nikomak'in Ahlâkı" (Nikomachische Ethik) adlı eserinde, kanun metninde düzenlenmemiş bir sorun hakkında konun koyucu nasıl bir kural koyacak idi ise, hakimin de bu sorunu bu yolla çözümlemesi ve kanunu tamamlaması gerekir düişüncesi yer almaktadır (bkz., İmre, s. 184, 185).

${ }^{58}$ Bkz., Honsell, FS Mayer- Maly, s. 383.

${ }^{59}$ Honsell, FS Mayer- Maly, s. 384. Bkz., Öztan/Öztan, s. 252, 253.

${ }^{60}$ Bkz., Öztan/Öztan, s. 252, 253; Ataay, s. 238, 239. Oysa Almanca metin "kanundan herhangi bir düzenleme çıkarılamazsa" şeklindedir.

61 "É défault d'une disposition légale applicable"

62 "nei casi non previsti dalla legge"

${ }^{63}$ Ataay, s. 238, 239. Aynca Bkz., Serozan, § 5, N. 21, s. 97.
} 
İsviçre Federal Mahkemesi 121 III 219'daki kararında amaca uygun sınırlandırmayı hakimin hukuk yaratmasında geçerli bir metot olarak kabul etmiştir ${ }^{64}$.

Tüm bu anlatılanların sonucunda hem gerçek olan-olmayan boşluk ayırımı, hem de bu kavramın hakkın kötüye kullanılması yasağına bağlanması ortadan kalkar $^{65}$. Hakkın kötüye kullanılması yasağı sadece amaca uygun sınırlamanın mümkün olmadığı durumlarda, yorum sonucunda açık adaletsizlikler ortaya çıkıyorsa uygulanabilir ${ }^{66}$.

Amaca uygun sınırlandırma ile boşluk doldurma, başlangıçtaki boşluklar için olduğu gibi, sonradan ortaya çıkan örtülü boşluklar için de mümkündür. Nitekim kanunun konulduğu sırada bilinmeyen, yeni öyle olaylar ortaya çıkabilir ki, bu olaylar mevcut kanunun amacına aykırıllk oluşturabilir ${ }^{67}$.

\section{3. Örtülü Boşlukların Amaca Uygun Sınırlama ile Doldurulmasına Örnekler}

BK 394/II (İBK 402/II)'ye göre, vekil vekaleti ifa dolayısıyla uğradığı zararların tazminini müvekkilden isteyebilir, ancak müvekkil kusuru olmadığını ispatlayabilirse sorumluluktan kurtulur. Ancak ücretsiz vekalet durumunda vekalet verenin sorumluluğu için kusurun aranması, vekaletsiz iş görme ile karşılaştırıldı̆̆ında eşitliğe ve hakkaniyete aykır sonuçlar doğmasına neden olur. Bu nedenle İsviçre Federal Mahkemesi bu hükmün ücretsiz vekalet sözleşmelerine uygulanmayacağına karar vermiştir ${ }^{68}$. Somut olayda bir kişi sağlık nedenleriyle bizzat yapamayacağından, komşusundan ağacın meyvelerinin toplanması için ricada bulunmuştur. Komşu, bu ricayı kırmamış, ağaca çıkarak meyveleri düşmesi için silkelemiş, ancak çok güçlii sarstığından üstünde bulunduğu dal kurılmış ve düşerek yaralanmıştır. Acaba komşuda yaralanma dolayısıyla meydana gelen zararları (hastane masrafları, iş gücünün kaybı) ağaç sahibi ödemeli midir? Haksız fiilin şartlan burada gerçekleşmemiştir. Çünkü ağaç sahibinin kusuru yoktur. Burada bir vekalet

\footnotetext{
64 "Amaca uygun sunirlamada kanun koyucunun kanun koyma yetkisine müdahale değil, zamana uygun metot anlayışına göre hakimin geçerli olarak hukuk yaratması söz konusudur... Boşluk kavramı kelimenin anlamının amaca uygun sınırlandırması sonucunda pozitif düzenlemenin bir kuraldan yoksun olması durumunda ortaya çıkar, bu durumda örtülü, ancak gerçek boşluk vardır ve hakimin hukuk yaratması ile doldurulur." BGE 121 III 219, 225, 226.

${ }^{65}$ Caroni, s. 152.

${ }^{66}$ Caroni, s. 152

${ }^{67}$ Bkz., Larenz/Canaris, s. 200, 2001; Kramer, bu durumda ikinci dereceden gerçek olmayan boşluk bulunduğunu belirtmektedir (Teleologische Reduktion, s. 76).

${ }^{68}$ BGE 61 II 95, 98.
} 
sözleşmesi söz konusudur. Vekalet verenin sorumlu olması için ise, BK 394/II'nin lafzına göre kusurlu olması aranır. Olayda vekalet verenin kusuru bulunmadığından, masrafların zarar görende kalması gibi bir sonuç ortaya çıkmaktadır. Oysa iş sahibin yararına vekaletsiz iş gören bile BK 413 uyarnnca işi görürken uğradığg zararın hakkaniyet dairesince tazminini isteyebilmektedir. Federal Mahkeme'ye göre buradaki soruna vekaletsiz iş görme hükümlerinin kıyas yoluyla uygulanması suretiyle bir çözüm getirilmelidir. Aksi takdirde yardımsever davranan vekilin vekaletsiz iş görenden (BK 411vd.) daha kötü durumda olması sonucu ortaya çıkmaktadır. $\mathrm{Bu}$ sonuç ise, kanunun bütünü göz önünde bulundurulduğunda eşitlik ilkesine ve hakkaniyete aykındır. Aslında bu hükümde örtülü boşluk söz konusu olup, BK 394/II'nin geniş tutulmuş kelime anlamı sadece ücretli vekalete uygulanacak şekilde sinırlandırılmalıdır ${ }^{69}$. Dolayısıyla ücretsiz vekalette vekilin iş görme nedeniyle uğradığı zararlan vekalet veren kusuru olmasa da tazmin etmelidir ${ }^{70}$.

$\mathrm{Bu}$ konuda bir başka örnek, temyiz gücü olmayanların hukuki işlemlerinin geçersizliğine ilişkin MK 15 hükmüdür ${ }^{71}$. MK m. 15/'e göre, temyiz gücü olmayan kişilerin yaptığı hukuki işlemler kesin olarak hükümsüzdür, taraflan bağlamaz. Kanunda bu konuda bazı istisnalar saklı tutulmuştur (MK 15/II). Ancak bunlar arasında temyiz gücü olmayanm geçersiz iş sözleşmesinden dolayısıyla yerine getirdiği hizmet ediminden ötürü ücret alacağının veya diğer işçi haklarının saklı kalacağına ilişkin bir istisna yer almaz ${ }^{72}$. Bunun gibi temyiz gücü olmayanın satın aldığı piyango biletine çıkan ikramiyeyi, kurduğu sigorta sözleşmesi gereği hak ettiği tazminatı ve kendisine bağışlanan değeri isteme hakkı da saklı tutulmamıştır. Oysa kanunun temyiz gücü olmayanın yaptığı işlemleri geçersiz kılmasının amacı temyiz gücü olmayanı korumaktır. Kanunun amacı esas alındığında kanunun lafzı çok geniş tutulmuş bu konuda gerekli istisnalara yer verilmemiştir. İşte bu durumda örtülï boşluk söz konusudur. Gerekli istisnanın hakim tarafından

\footnotetext{
${ }^{69}$ Bkz., Caroni, s. 153; Meier-Hayoz, Schlusswort, s. 91; Kramer, Teleologische Reduktion, s. 72, 73; Kramer, Methodenlehre, s. 163.

${ }^{70} \mathrm{Bu}$ sonuç doktrinde kabul edilmektedir. Bkz., Fellmann, Art. 402, N. 140, 179 vd.; Gautschi, Art. 402, N. 23; Aral, s. 431; Tandoğan, II. s. 602.

${ }^{71}$ Bkz., Serozan, $\S 5$, N. 16, s. 92. Serozan örtülü boşluklar konusunda bu örneği vermekte, ancak daha önce de belirttiğimiz gibi bu boşluğun ancak normun somut olaya uygulanmasının hakkın kötïye kullanılması niteliğini taşıdığı takdirde hakim tarafından düzeltilebileceğini kabul etmektedir. Oysa biz, hakkın kötüye kullanılması yasağının somut olayda gerçekleşip gerçekleşmediğini aramadan önce, örtülü boşluk durumunda bunun amaca uygun sınırlama ile MK 1'e göre doldurulacağı görüşünü savunuyoruz. Örtülü boşluk bulunmadığı takdirde kanunun somut olaya uygulanması hakkın kötüye kullanılmasını niteliğindeyse, MK 2/II'ye başvurma konusunda hiçbir engel bulunmamaktadır.

${ }^{72}$ Bkz., Serozan, § 5, N. 16, s. 92.
} 
konulması, temyiz gücü bulunmayanın tamamen yararına olan işlemlerde, hukuki işlemi geçerli saymakla gerçekleşir.

İsviçre Federal Mahkemesi ${ }^{73}$ bir sözleşmenin gabin nedeniyle sakatlığ durumunda sözleşmenin tamamının geçersizliğine (feshedilebileceğine ${ }^{74}$ ) ilişkin IBBK 21 (BK 21) maddesinin lafzının, kanunun amacı ve ruhuna uygun olmadığı, bu nedenle sözleşmenin fahiş olmayan bir fiyatla (edimler arasında aşırı oransızlık bulunmayacak bir şekilde) devam etmesi gerektiğine karar vermiştir. Mahkeme İBK 21'in amacı esas alınarak sınırlandırılmasını (Reduktion) kabul etmiştir ${ }^{75}$. Federal Mahkeme'ye göre, bu hükmün amacı gabine uğrayan kişinin korunmasıdır. Ancak sadece sözleşmeyi iptal etme hakkının tanınması, gabine uğrayanın korunması için yeterli değildir. Özellikle bu durum gabine uğrayan tarafın zor durumda kalması nedeniyle sözleşmeyi kabul etmesi halinde kendini gösterir. Sadece sözleşmeyi iptal hakkını

${ }^{73}$ Federal Mahkemeye göre, günümüzde "sosyal özel hukuk" gittikçe artan bir ölçüde güçlenmektedir. Maddi sözleşme adaleti şekli sözleşme hürriyetini bastırmıştır. Bu, özellikle kira ve iş hukuku, tüketicinin korunması ve genel işlem şartlan alanunda kendini göstermektedir. Günümüzdeki hukuk düşüncesi, özel hukuk işlemlerinin geçerliliği ve butlanı konusunda siyah ve beyaz gibi kesin çizgilerden oluşmamaktadır, bunların arasında hakimin içerik kontrolü ile sınırlandırmalar yaptığı gri alanlar da gittikçe artan (güçlü) bir ölçüde yer almaktadır. Hakimin sözleşmeye müdahale imkanı zamanın ruhuna uymaktadır. Hukuk uygulaması bunu görmezlikten gelemez. Dolayısıyla edimler arasında aşırı oransızlık bulunan sözleşmelerin kısmi butlanı günümüzde geçerli olan temel ilkelere uygundur. $\mathrm{Bu}$ sonuç kanunun sistematiğine de uygundur .. Hukuki işlemin kısmi butlanı ilgili normun amacından da çıkmaktadır, öyle ki uygulanacak normun kapsamı, lafzının ötesinde amaca uygun sınırlandırılmaktadır. Salt kısmi butlan böylece doğrudan doğruya yasak koyan normun sonucudur ve uygun farazi taraf iradesi kısmi butlan için şart değildir. Farazi irade olsa olsa uygun hukuki sonucun, yani yedek hukuk kuralının içeriğinin belirlenmesi açısından önem taşır. Bu, sadece oransızlığın nicelik açısından indirilmesi değil, ayrıca nitelik açısından bir sözleşme düzenlemesi gerektiği durumlarda zorunludur. Doğru olan, kanuni düzenlemeye aykın olan sözleşmenin sadece ihlal edilen normun amacı ve ruhu bunu gerektiriyorsa geçersiz olmasıdır (BGE 123 III 292 vd., 298, 299).

${ }^{74}$ IBK 21 'de "zarar görenin sözleşme ile bağlı olmadığını" bildirebileceği hükme bağlanmıştır. Türk hukukundaki hakim görüş, gabin halinde de irade sakatlıklarında olduğu gibi iptal müeyyidesinin uygulanmasıdır (bkz ., Eren, s. 392; Oğuzman/Öz, s. 115).

${ }^{75}$ BGE 123 III 292 vd., 297- 299. Aynı görüşte Kramer, Art. 21, N. 49, 53. Gauch, bu sonucu IBK 20/II (BK 20/II)'ye dayanarak geliştirilen değiştirilmiş kısmi butlan düşüncesini (değiştirilmiş kısmi butlan konusunda bkz., Başpınar, Veysel: Borç Sözleşmele rinin Kısmi Butlanı, Ankara 1998, s. 154 vd.) 21. maddeye aktararak kabul etmektedir. Bu durumda taraflarn farazi iradesi indirilmiş hadle sözleşmeyi yapacakları yönündeyse, sözleşme bu değiştirilmiş haliyle devam eder (bkz., Gauch, Peter: Der Fussballclub un sein Mietvertrag: Ein markanter Entscheid zur Übervorteilung, BGE 123 III 292, recht 1998, s. 55 vd.; Gauch/Scluep/Schmid/Rey, N. 754. Aynca bkz., Eren, s. 392). Federal Mahkeme'nin bu kararı üzerinde düşünceler konusunda bkz., Buz, Vedat: Gabin Halinde Aşırı Oransızlığın Giderilerek Sözleşmenin Ayakta Tutulması, BATIDER 1998, C. XIX, Sayı.4, s. 53 vd. 
tanımak, ona ya karşı edimden vazgeçerek eski zor durumuna dönme ya da sözleşmeyi olduğu gibi kabul etme tercihlerinden birini yapmaya zorlamaktadır. Oysa edime ihtiyą̧ duyan taraf sözleşmeyi iptal etmek istemeyecektir. $\mathrm{Bu}$ durumda ise $\mathrm{BK} 21$ 'in zor durumda olanı koruma

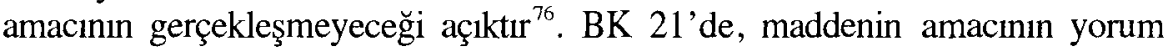
sonucunda elde edilen geniş kelime anlamı dolayısıyla gerçekleşmemesi nedeniyle oluşan örtülü boşluk, bu düzenleme ile sağlanmak istenen gabine uğrayanın korunması amacının gerçekleştirilmesi için sözleşmenin uygun fiyatla devam etmesi yoluyla doldurulur.

Kramer, vekalet sözleşmesinin taraflarca her zaman geri alınabileceğine ${ }^{77}$ (vekaletten azil ve istifa edilebileceğine) ilişkin düzenlemeyi (IBBK 404/I, BK 396/I) örtülü boşluklara örnek olarak göstermektedir ${ }^{78}$. Söz konusu düzenleme ücretsiz vekalet ve çok yoğun güven ilişkileri göz önünde bulundurularak konulmuştur. Ancak bu düzenleme yapılırken tüm vekalet sözleşmelerine uygulanacak şekilde geniş kapsamlı bir ifade kullanılmıştır. Oysa günümüzde vekalet sözleşmeleri çoğunlukla ücretli yapılmakta, taraflar arasında güven ilişkisinin yoğun olmadığı vekalet sözleşmeleri de bulunmaktadır. Sözleşmenin her zaman geri alınılabileceğine ilişkin BK 396/I hükmünün, söz konusu bu durumları da kapsaması kanunun amacindan çıkarılamadığı gibi, Borçlar Kanunun genel sistematiği de bunu destekler nitelikte değildir. Dolayısıyla, bu normun lafzı çok geniş kapsamlı olup, ücretli vekalette ve güven ilişkisinin çok yoğun olmadığ durumlarda istisna yapılmasını gerektirmektedir ${ }^{79}$. Burada örtuilii boşluk vardır. Bu boşluk, vekalet sözleşmesinin her iki tarafça her zaman feshedilebileceğine ilişkin hükmün, ücretli vekalete ve güven ilişkisinin çok yoğun olmadığı sözleşmelere uygulanmaması yoluyla doldurulmalıdıro ${ }^{80}$. Böylece sürekli borç

\footnotetext{
${ }^{76}$ Kramer, Art. 21, N. 53.

${ }^{77}$ Burada vekalet sözleşmesinin tek taraflı varması gereken irade beyanıyla ile ileriye etkili olarak sona erdirilmesi söz konusudur (Bkz., Tandoğan, s. 620, 621; Aral, s. 432).

${ }^{78}$ Kramer, Methodenlehre, s. 145, 164, dn. 568; Kramer, Teleologische Reduktion, s. 68.

${ }^{79}$ BkZ, Bär, ZBJV 1985, s. 226. Doktrinde 396/I hükmünün emredici nitelikte olup olmadı̆g tartışmalıdır. Bu konuda hakim görüş, ücretsiz veya ücretli olmakla birlikte taraflar arasındaki güven ilişkisinin çok yoğun olduğu (mesela hekimlik, avukatlık ilişkisi gibi) sözleşmeler tipik vekalet olup, bunların her zaman feshedilebileceğini kabul etmektedir. Bu durum emredici nitelikte olup, aksi kararlaştırılamaz. Bunun dışındaki vekalet sözleşmeleri ise, atipik olup, bu sözleşmelerin her zaman feshedilmeyeceğine ilişkin anlaşma yapılabilir (bkz., Gauch, recht 1992, s. 15 vd.; Fellmann, Art. 404, N. 115 vd;; Bucher, BT s. 28; Aral, s. 433).

80 İsviçre Federal Mahkemesine göre "Kanunun açik lafzı bir ayırım yapmaya izin vermemektedir, bu nedenle Art. 404 hem gerçek ve ücretli vekalete hem de ücretsiz ve şahsa sıkı sıkıya bağlı diğer vekalet ilişkilerine uygulanır" (BGE 115 II 464). Bu karar hakkındaki eleştiriler için bkz., Gauch, recht 1992, s. 9 vd., 21.

Meier-Hayoz'a göre “Geniş lafza körü körüne bağlı olmak, hakimin normun amacı esas alınarak belirlenen dar anlamın görmesini (bu anlama nüfuz etmesini) engellemektedir. Hakim
} 
ilişkisi niteliğindeki ücretli vekalet sözleşmelerinin sona ermesi, sürekli borç ilişkilerinin sona ermesine dair genel kurallarla uyum içerisinde olur. Oysa Federal Mahkeme kanunun açık lafzının ayınm yapmaya izin vermediğini belirterek, bu hükmü tüm vekalet ilişkilerine uygulamaktadır ${ }^{81}{ }^{82}$.

BK'nun 183. maddesinin birinci fikrasında satılan malın yarar ve hasarının sözleşmenin kurulması ile birlikte alıcıya geçeceği düzenlenmekte, ikinci fikrasında satılan çeşit borcu ise, yarar ve hasann alıcıya geçmesi için ayrılmış ve eğer malın başka yere gönderilmesi söz konusu ise satıcının satılan üzerinden elini çekmiş olması aranmaktadır. Gönderme suretiyle yapılan mesafeli satımlarda, çeşit borcunda yarar ve hasarın alıcıya geçmesi için

kanunun amacını (ratio legis) araştırmadan, lafızla (verba legis) yetinmektedir. Bu yanlış tutumun düzeltilmesi zor değildir: Burada da her lafzın (söz de açık olan lafızların bile) mutlaka yorumlanması gerektiği hatırlanmalıdır. Scire leges non hoc est, verba earum tenere, sed vim ac potestatem "Kanunlan bilmek, tanımak onların kelimelerine bağlı kalmak değil, onların gücuine ve yeterliliğine bağlı olmaktır, Dig.1,3,17(Celsus)" (Schlusswort, s. 90).

${ }^{81}$ BGE 115 II 464; BGE 104 II 108, 115; 109 II 462.

82 İsviçre Federal Mahkemesi el yazısı ile vasiyetnamenin düzenlenmesi konusunda da kanun metnine aynı derecede sıkı sıkıya bağlı kalmaktadır. BGE 116 II 117'de içerik olarak doğru olmayan düzenleme zamanının, 117 II 145'de düzenleme yerinin her halükarda vasiyetnamenin iptaline neden olmayacağına iliş̧kin verdiği kararlardan sonra, BGE 117 Il 246'de dikkatsizce yanlış yazılmış düzenleme yerinin mutlaka vasiyetnamenin geçersizliği sonucunu doğuracağına karar vermiştir. BGE 117 II 246'da Federal Mahkeme, miras bır akanın düzenleme gününü ve ayını yazmış olmasına rağmen yılını yazmayı unutmuş olması (Azmoos, 18 Ekim) nedeniyle vasiyetnameyi geçersiz saymıştır. Oysa somut olayda yılın yazılmamış olması herhangi bir önem taşımamaktadır. Ancak Federal Mahkeme IMK 505 (BK 485)'in lafzını aşılamayacak bir engel olarak kabul etmiştir. Bu hüküm açık olarak düzenleme yerini, yılını ve ayını aramaktadır. Federal Mahkeme kanunun açık hükmü göz önünde tutulmazsa, bu durumda hakime yorum metoduyla hukuk yaratma yolu açlır ve bu da kanun koyucunun kural koyma yetkisine miidahale anlamını taşır görüşüundedir. Druey,'e göre burada sorun, şekil kurallarının somut olayda amaca uygun sinrlamaya izin verip vermeyeceğidir (bkz., Druey, Jean Nicolas: Grundriss des Erbrechts, 3. Aufl ., Bern 1992, s. 100) .

Yargitay 1990 yılına kadar el yazısı ile vasiyetnamede düzenleme yerinin el yazısı ile olmasını geçerlilik şartı olarak aramaktayd. Yargıtay 2.HD. 10 5. 1990 tarih ve 12841/4057 sayılı kararıyla görüş değiştirmiştir. Bu karara göre, "Vasiyetnamede düzenleme yerinin bulunmasını zorunlu kılan gerçek hukuksal neden ona uygulanacak yasanın belirlenmesidir. Türkiye'de bir tek hukuk sistemi bulunduğuna ve "kanun ihtilafı" söz konusu olmayacağına göre, düzenleme yerinin el yazısıyla vasiyetnamede yer almasını geçerlilik koşulu olarak kabul etmek, hukukumuzdaki birlik yönünden aşır düzenlenmiş bir çözüm olur. ... Alındığı tarihten beri çok az değişiklik gören Türk Medeni Yasasının bu konuya değinen hükmünün, olması gereken hukuk açısından ele alınıp, yorumlanması zamanı gelmiştir. Kişi ve toplum için yarar sağlamayan, tarihi etkinliğini yitirmiş olan koşullarm katı bir yorumla uygulanmasında direnme modern yorum kurallanyla da bağdaşmaz" (YKD 1991, C. XVII, s. 535). Bu karann eleştirisi için bkz., Kılıçoğlu, Ahmet: El Yazılı Vasiyetnamede Düzenleme Yeri, Akipek'e Armağan, Konya 1991, s. 327vd.

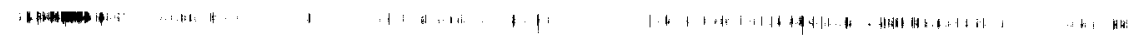


satıcının mal üzerindeki hakimiyetini bırakmış olması aranırken, parça borcunda bunun aranmaması birbiriyle çelişki oluşturduğu gibi, kanunun amacına da ters düşmektedir ${ }^{83}$. BK 183/II'deki çeşit borcu için kabul edilen düzenleme, kanunun amacı gereği parça borcu için de geçerli olmalıdı $\mathrm{r}^{84}$. BK 183/I'de örtülü bir boşluk bulunmaktadır ve 183/II kıyasen uygulanarak sinırlandirıl-malıdır ${ }^{85}$.

Örtuilii boşluklar konusunda Alman Hukukundaki çarpıcı örneklerden biri, somut olayda menfaat çatışmasının bulunmadığı durumlar açısından bir istisna getirmemiş olması dolayısıyla AMK $181 \mathrm{dir}^{80}$.

\section{IV. Örtülü Boşlukların Doldurulması ve Daraltıcı Yorum Arasındaki İlişki}

Örtülü boşlukların doldurulması ile daraltıcı yorum aynı şeyler değildir ${ }^{87}$. Çünkü daraltıcı yorum, kanundaki kelimelerden çıkanlabilecek anlam

83 Bkz., Koller, Honsell/Vogt/Wiegand (Hrsg.), Kommentar zum Schweizerischen Privatrecht, Obligationenrecht I, 2. Aufl., Basel-Frankfurt 1996, Art. 185, N. 15; Atamer, Yeşim: Satım Sözleşmesinde Hasarın İntikali Anı, Hukuk Tarihi, Karşlaş̧ırmalı Hukuk ve Milletlerarası Hukuk Açısından BK 183'ün Farklı Okunması Gereği, Oğuzman'ın Anısına Armağan, İstanbul 2000, s. 131 vd., 145 vd., 148.

${ }^{84}$ Bkz., Koller, Art. 185, N. 15; Cavin, Pierre: Schweizerisches Privatrecht, (Hrsg. Frank Vischer), Bd. VII, Basel und Stuttgart 1977, Kauf, Tausch und Schenkung, s. 1 vd., 37.

${ }^{85}$ Bkz., Kramer, Methodenlehre, s. 164, dn. 568; Atamer, bu iki hüküm arasındaki çelişkileri giderme yollarından birinin 183. maddeyi MK 2 aracılığıla amaca uygun sinırlamaya tabi tutmak olduğunu belirtmektedir (s. 148). Ancak biz amaca uygun smirlamanın örtülü boşlukların doldurulmasında bir yöntem olduğunu ve bu durumda MK 1'in uygulanması gerektiğini savunmaktayız.

${ }^{86}$ Türk hukukunda yer almayan bu hükme göre, temsilcinin temsil olunan için temsilci sıfatıyla, kendisi ile yaptığı sözleşmeler (temsilcinin kendi kendisiyle sözleşme yapması) geçersizdir. Bu düzenlemenin amacı temsil edileni, aralarındaki hukuki ilişkide muhtemel menfaat çatışmalannda temsilcinin kendisinin menfaatine olup, temsil edilenin aleyhine bir durumu seçme ihtimalinden korumaktır. Temsilcinin kendi kendisiyle işlem yapması, temsil edilenin menfaatlerini az da olsa ihlal ediyorsa sözleşmenin geçersiz olması gerekir. Ancak, böyle bir zarar tehlikesi hiç yoksa, bu işlem tamamen temsil olanın menfaatine ise burada bir sunılama yapılması haklıdır. Bir işlemin temsil olunan hesabına sadece bir yarar getirip getirmediği sorusu, olayda taraflar arasında bir menfaat çatışması olup olmadığı ve böylece menfaatlerin tehlikeye düşüp düşmediği sorusuna nazaran çok daha kolay cevaplandırılır. Bu sorunun cevaplandırılması açısından ortaya çıkan belirsizlik, her yorum sorunundan daha biuyük değildir ve göze alınması gerekir. Bu nedenle amaca uygun sinırlandırma bu kapsamda hem geçerli, hem de amaca ve ruha aykırı sonuçların önlenmesi için gereklidir (Larenz/Canaris, s. 212).

${ }^{87}$ Kramer, s. 162 , dn. 560. 
(kelimelerin mümkün olan anlamı) ile sinırlıdır ${ }^{88}$. Daraltıcı yorumda, bir normun kelime anlaminın kapsamına girip girmeyeceği belli olmayan seçenekler, kapsama dahil edilmeyip, düzenlemenin geçerlilĭği kelime anlamının çekirdek alanı ile sınırlanır ${ }^{99}$. Oysa örtülü boşlukların amaca uygun sinırlama ile doldurulmasında, söz konusu normun kavram kapsamina gireceği açık olan seçenekler kapsama dahil edilmez, çünkü onlar amaca dahil değildir $^{90}$.

Örtülü boşlukların doldurulması ile daraltıcı yorum arasındaki sınır kesin değildir, birbirinin içine girmiştir ${ }^{91}$. Çünkü bir unsurun bir normun kelime anlamının kapsamına girip girmeyeceğinin açıkça belirlenmesi her zaman mümkün değildir. Somut olayda daraltıcı yorumun mu, yoksa amaca uygun sınırlandırmanın mı söz konusu olduğu şüpheli olabilir². Uygulamada aslında

${ }^{88}$ Bkz., Canaris, s. 82; Haefelin, FS Nef, s. 123; Zeller, s. 153 vd.,156, 480; Kramer, Methodenlehre, s. 39 vd.; Zippelius, s. 43, 44; Neuner, s. 91 vd. 102; Zippelius, Reinhold: Auslegung als Legitimationsproblem, FS Larenz, München 1980, s. 748. Meier-Hayoz'a göre, geniş lafız yorum yoluyla dar bir anlam kazanırsa (= teleologische Reduktion), bu durumda boşluk değil, kanunun yorumu alanında bulunulur... Amaca uygun sınırlama ile doldurulması gereken bir boşluk tespit edilirse, bu taktirde istisnai veya gizli boşluk söz konusudur (Schlusswort, s. 91).

${ }^{89}$ Kramer, s. 46, 47, 162, dn. 560.

${ }^{90}$ Canaris, s. 83. Belirsiz kavramların uygulanmasında, bu kavramın uygulanacağı açıç̧a belli olan öğeler pozitif seçenek (Kandidat), bu kavramın uygulanmayacağı açıkça belli olan öğeler ise negatif seçenek, buna karşılık bu kavramın uygulanıp uygulanmayacağı konusunda karar verilmemiş olan öğeler ise nötr seçenek olarak ifade edilir (Kramer, Methodenlehre, s. 46, 47, 162 , dn. 560).

${ }^{91}$ Bkz., Kramer, Methodenlehre, s. 39 vd., 41. İsviçre doktrininde hakimin kanunun lafzına sıkı bir şekilde bağlı olmak zorunda olmadığı, onun ötesine gidebileceği kabul edilmektedir (bkz., Meier-Hayoz, Art.1, N. 135, 175 vd.). Zira hakim İMK 1/I'e göre, kanunu lafzına veya yorumuna göre uygulayacaktır. Federal Mahkeme, kanunun yapılış tarihi, sistematik yeri, amacı ve ruhundan lafzın, düzenlemenin gerçek amacını ortaya koymadığını gösteren haklı nedenler varsa lafızdan ayrılınılabilir görüşündedir (BGE 87 I16;103 Ia 14; 111 Ia 297). Bu şekilde lafızdan ayrulma imkanı ise, yorumu boşluk doldurmaya güçlü bir ölçüde yaklaştırmaktadır, öyle ki bu durumda her ikisi arasındaki farklılıkları tespit etmek mümkün olmamaktadır (Haefelin, FS Nef, s. 121, 122). Rhinow'a göre de kanunun lafžnın ötesine giden amaçsal yorum "maske takmış (kılık değiştirmiş)" bir hukuk yaratmadır (s. 46).

${ }^{92}$ Hem doktrinde hem de uygulamada yorum alanı ile boşluk arasındaki ayırımı belirleyen kriterlerin kesin olmadığı, metodolojik açıdan ise bu ikisi arasında temel bir farklılık bulunmadığı kabul edilmektedir (bkz., Dürr, Art. 1, N. 269, 405; Merz, Symposium, s. 59 vd.; Kramer, Methodenlehre, s. 39 vd.; Larenz/Canaris, s. 187, 188; Öztan/Öztan, s. 252. BGE 121 III 219, 226). Genel olarak yorumda bir normun lafzı, oluşum tarihi, amacı ve sistematik yeri dikkate alınarak onun ruhu ortaya konulur. Buna karşllik boşluk doldurmada norm bulunan bir başka düzenleme ile tamamlanır. Dolayısıyla boşluk doldurmada yaratıcılık payı çok daha fazladır. Bununla birlikte yorum ile boşluk doldurma arasındaki fark abartılmamalıdır. Çünkü yorum da aynı zamanda yaratıcı bir faaliyettir. Diğer taraftan boşluk 
amaca uygun sınırlamanın bulunduğu bir çok yerde, daraltıcı yorumdan bahsedildiği görülmektedir ${ }^{93}$. Zira uygulayıcılar yorum yaptıklarında kanuna bağlı oldukları intibaını yarattıkları düşüncesindedirler. Ancak amaca uygun sınırlama da, kanunun gerçek amacına yönelmiş olduğu ve bu amacın gerektirdiği simırlara dikkat ettiği için amaca uygun yorum kadar kanuna bağlıdır ${ }^{94}$. Burada kanuna aykır bir hukuk yaratma (Rechtsfindung contra legem) söz konusu değildir, çünkü kanunun değerlerinin smırları içerisinde kalınmaktadır ${ }^{95}$.

\section{V. Örtuilü Boşlukların Amaca Uygun Sinırlama Yoluyla Giderilmesinin Sınırları}

Örtülï boşluların amaca uygun sınırlama yoluyla doldurulmasında dikkat edilmesi gereken bazı ilkeler bulunmaktadır. Bunlar aşa ğıdaki gibi suralanabilir:

1. Amaca uyun sintrlama yoluyla kanunun düzeltilmesi pozitif hukukun değerlerine göre açıklanabilir nitelikte, bu değerlerle uyum içerisinde olmalıdir.

Amaca uygun sinurlama yaparken kanunun amacı (ratio legis) esas alınmaktadır ${ }^{96}$. Bu amacı belirlerken başvurulacak kaynak ise pozitif hukukun değerleridir. Pozitif hukukun değerleriyle uyum içerisinde bulunulmadığ takdirde, kanunun geniş tutulmuş lafzı sınırlanamaz ${ }^{97}$. Hakim amaca uygun sınırlama yaparken kendi değerlerini takip edeme $z^{98}$. Dolayısıyla burada

doldurmada da, kanunun amacı ve değerlerine bağlı kalınma söz konusudur. Her ikisi arasındaki nüanslann ortadan kalkması mümkündür. Her halükarda yorum her zaman boşluk doldurmanın bir safhasıdır (bkz., Haefelin, FS Nef, s. 122). Aynca bkz., Fikentscher, s. 310, 358,370 .

${ }^{93}$ Bkz., Dürr, Art.1, N. 272; Larenz/Canaris, s. 211; Larenz, Methodenlehre, s. 391.

${ }^{94}$ Larenz/Canaris, s. 211 ; Larenz, s. 391.

95 Canaris, s. 83.

${ }^{96}$ Kramer, Methodenlehre, s. 170, dn. 594.

${ }^{97}$ Bkz., Kramer, Methodenlehre, s. 166; Canaris, s. 71 vd., 83; 189, 190, 193, 203; Brandenburg, s. 71; Hausheer/Jaun, ZBJV 1998, s. 501 vd., 504 vd.

${ }^{98}$ Bkz., Brandenburg, s. 71. Hakimin amaca uygun sınırlamaya ilişkin verdiği kararların özel bir özenle gerekçelendirilmesi şarttır. Lafızdan aynlan karar gerekçelerinin mutlaka kuşkuya yer vermeyecek şekilde olması, açıkça ortaya konması gerekir. Sadece amaca uygun sınırlamanın uygulandığını belirtmek yeterli bir gerekçe olamaz (Hausheer/Jaun, ZBJV 1998, s. 504 vd., 510). "Kanun önce lafzına, amacı ve ruhuna ve temelinde yatan değerlere göre yorumlanır. Yorum mahkemenin kendi sübjektif değerlendirmelerine göre değ il, kanun koyucunun beyan ettiklerine göre belirlenen amaca (ratio legise) yönelir. Kuvvetler aynllğı ilkesinin denge düşüncesi, sadece geleneksel anlamda kanunun yorumlanmasını değil, bunun ötesinde yorumda 
hakimin kanuna bağlı kalmadığı söylenemez. Çünkü normun amacı, normun somut olaya uygulan-mamasını gerektirmekte, hatta uygulanmasını yasaklamaktadır. Böylece lafza bağlı olmanın ötesinde amaca bağlılık söz konusu olmaktadır ${ }^{99}$. Lafzı ile uygulanan norm, hukuki sorunları adalete uygun bir şekilde çözme fonksiyonunu yerine getirememektedir. Hakimin kanuna bağlı olması, onun kelimelerinin yorumu sonucunda zorunlu olarak harflerine bağlı olmak değil, amacı ve ruhuna bağlı olmaktır (MK 1).

$\mathrm{Bu}$ durumda özellikle söz konusu normun pozitif hukukun değerleriyle uyum içinde olup olmadığının belirlenmesi önem taşımaktadır ${ }^{1(x)}$. İsviçre doktrin ve uygulamasında çocuğun velayet hakkının IMKK, 297/III'ün ${ }^{101}$ açık lafzına rağmen boşanmış eşlerin her ikisine birlikte verilip verilemeyeceğinin belirlenmesinde pozitif hukukun değerlerine uygun olup olmadığ tartış1mıştı $^{102}$. BGE 117 II 523'de Federal Mahkeme, velayetin boşanmı̧

kullanılan yöntemlerin, hakimin hukuk yaratması alanında da ölçü alınmasımı gerektirir, öyle ki bir normun ön planda açık lafzı ya kıyas yolu yla onun tarafından kapsanmayan bir olaya (olayı içine alacak şekilde) genişletilir veya tam tersi, böyle bir olaya amaca uygun sinırlama yoluyla uygulanmaz" (BGE 121 III 219, 224, 225).

99 Brandenburg, s. 59

${ }^{100} \mathrm{Bu}$ değerler belirlenirken acaba kanunun konulduğu strada kanun koyucunun sahip olduğu değerler mi esas alınacak, yoksa toplumdaki değişmeler ve gelişmeler sonucunda oluşan değerler mi dikkate alınacaktır sorunu, sübjektif yorum yönteminin mi, yoksa objektif yorum yönteminin mi kabul edilmesi tartışmasıyla paralellik göstermektedir. Bu konuda genellikle kabul edilen görüş objektif yorum yöntemi olup, bunu yaparken kanun koyucunun kanunu çıkarma amacını yani tarihi nedenleri de göz önünde bulundurmaktır. Günümüzdeki metot anlayışı sübjektif yönteme mutlak geçerlik tanımayı reddettiği gibi, kanunun oluşum tarihini de tamamen bir tarafa bırakan objektif yöntemi de istisnasız kabul etmemektedir (bkz., Hausheer/Jaun, ZBJV 1998, s. 506; Kramer, Methodenlehre, s. 88 vd., 101 vd. Yorum yöntemleri konusunda bkz., Zippelius, Reinhold: Auslegung als Legitimationsproblem, FS Larenz, Müchen 1980, s. 739 vd.). Bu yöntemlerden hangisine öncelik tanınması gerektiği öteden beri tartışılmaktadır. Federal Mahkemenin kararlan yeknesak olmasa da, objektif tarihi metoda ağırlık tanıdığı görülmektedir. Dolayısıyla zaman içinde değişen şartlara uyum sağlamak reddedilmemektedir. Federal Mahkeme kanun koyucunun açık düzenleme amacını ve bu amacı takip eden değerleri bağlı kalınması gereken değerler olarak kabul etmektedir (116 II 527). Neuner'e göre, hakim objektif- amaçsal açıdan başka bir şekilde davranılması gerekmediği takdirde, tarihi kanun koyucunun iradesiyle bağlıdır (s. 115).

${ }^{101}$ Bu hüküm IMK'ya 1976 yılında yapllan değişiklikle eklenmiştir. Türk hukukunda aynlıkta ve boşanmadan sonra ortak velayet kabul edilmemektedir (MK 148, 264, bkz., Akıntürk, Aile Hukuku, 4. bası Ankara 1996, s. 271 vd.; Serozan, Çocuk Hukuku, İstanbul 2000, s. 202). MK Tasansında ise "Ortak hayata son verilmiş veya aynlık hali gerçekleşmişse hakim, velayeti eşlerden birine verebilir.- ..Velayet ana babadan birinin ölümü halinde să̆ kalana, boşanmada ise çocuk kendisine bırakılan tarafa aittir" hükmü yer almaktadır (336/II-III).

${ }^{102}$ Bu konudaki tartışmalar ve kararlar konusunda bkz ., Dürr, SJZ 1996, s. 322; Sandoz, SJZ 1996, s. 219; Müller, SJZ 1997, s. 457; Marti, SJZ 1998, s. 248; Hausheer/Jaun, ZBJV 1998, s. 501 vd., 505 vd. BGE 123 III 445. 
eşlerin her ikisine birden verilmesi konusunda olan hukukun değerleri esas alındığında amaca uygun sınırlama yapılamayacağına karar vermişti ${ }^{113} .1998$ yılında İsviçre Medeni Kanununda yapılan değişiklikle, boşandıktan sonra veya evli olmayan ana baba arasında ortak velayetin seçimlik bir hak olması kabul edilmiştir ${ }^{104}$.

\section{Düzenlemenin niteliği amaca uygun sintrlama yaptlmastna izin vermelidir.}

Hukuk güvenliğine öncelik verilmesi gereken durumlar, norma bağlı kalınmasını gerektiriyorsa amaca uygun sinırlama yasağı vardır ${ }^{105}$. Bu durumda düzenlemenin niteliği amaca uygun sinırlamaya izin vermemektedir. Düzenlemenin niteliği gereği amaca uygun sinırlandırmanın yapılamayacağı durumlarda genellikle "katı düzen kuralları" söz konusu olmaktadır ${ }^{106}$. Zira katı düzen kurallan, konulma amacından bağımsızdır ${ }^{107} . \mathrm{Bu}$ açıdan hukuki açıklık ve güvenlik somut olay hakkaniyetinden önce gelir. Dolayısıyla süre ve şekil kurallarında ve benzer hukuk tekniğine ilişkin düzenlemelerde belli bir

${ }^{103}$ Buna karşılık St. Gallen Bölge Mahkemesi Art. 297, Abs. 3’ün asıl amacının çocuğun yaranna en uygun çözümün bulunması olduğunu, bu nedenle açık lafızdan aynlan, onu amaca uygun sınırlayan çözümden hareket edilmesi gerektiğini, dolayısıyla bazı şartlanını bulunması halinde, ortak velayete karar verilebileceğine hükmetmiştir (bkz., 8. 11. 1988, ZBJV 1989, s. 139 vd. Aynca bkz., 22. 3. 1994, SJZ 1996, s. 129). Federal Mahkeme daha sonraki bir kararında, IMK 297/III'da hakimin düzeltebileceği bir hukuk politikası boşluğu (gerçek olmayan boşluk) bulunmadığı, çünkü bu normun uygulanmasının hakkın kötüye kullanılması niteliğinde olmadığın belirterek, boşanmadan sonra çocuğun velayetinin her iki eşe birden verilmeyeceğini kabul etmiştir (BGE 123 IIl 445). Federal Mahkeme, bu kararında kanun koyucunun değer yargılarının (Werturteil) boşanmadan sonra ortak velayetin tanınmamasının çocuğun yarannı en iyi koruyacak araç olduğu şeklinde belirdiği görüşündedir. Aynca bkz., Hausheer/Jaun, ZBJV 1998, s. 501 vd.

${ }^{104}$ Ana baba, çocuğun bakımı konusunda kendilerine düşenin ve masraflarının paylaşımı konusunda onaylanması gereken bir anlaşmaya vanrlarsa, her ikisinin ortak talebi üzerine mahkeme, bunun çocuğun menfaatleriyle uyuşması halinde, ortak velayete karar verir (IMM 133/III, 298a) (BBI 1996 I 125, Ziffer 233.62, 244, 41). Bkz., Hegnauer, Cyril: Grundriss des Kindesrecht, Bern 1999, s. 186, N. 25.21b

${ }^{105}$ Bkz., Larenz, Methodenlehre, s. 392; Honsell, FS Mayer-Maly, s. 386.

106 Bkz., Canaris, s. 192; Merz, Auslegung, Lückenfüllung und Normberichtigung, AcP 1963, s. 305vd., 314 vd. AMK 181'de yer alan temsilcinin kendi kendisiyle sözleşme yapma yasağı, önceleri şekli düzen kuralı olarak nitelendirilmiş ve dar yorumlanması gerektiği savunularak, hukuk güvenliği gereği amaca uygun sınırlandırlamayacağı kabul edilmişti. Ancak daha sonra temsilcinin kendi kendisiyle işlem yapması hiçbir şekilde temsil edilenin zararına değ $i l$, tamamen onun yaranna ise, bu takdirde amaca uygun sinılamanın mümkün olacağ kabul edilmiştir. Bu yasağın hukuk güvenliğinin gerektirdiğinden daha fazla bir alana yaygınlaştırıması haklı değildir (bkz ., Larenz, Methodenlehre, s. 392, 393).

${ }^{107}$ Bkz., Honsell, FS Mayer-Maly, s. 386. 
açıdan amaca uygun sınırlama yapılamaz ${ }^{108}$. Örneğin hiç kimse bir kişinin 17 yaşında yeterli olgunluğa erişmiş olduğunu ileri sürüp, onu tam ehliyetli olarak nitelendirerek, MK 10 hükmünü uygulayamaz. MK 11 hükmünü koyarken kanun koyucu kişilerin sadece belli bir olgunluğa erişme yolunu göstermiş, onu da 18 yaşın tamamlanması olarak düzenlemiştir.

Bunun gibi şekle ilişkin bir kural, aceleci olmayı engellemeye hizmet ediyorsa, taraflann tecrübeli olduklan, böyle bir korumaya ihtiyaçlan bulunmadığı iddia edilerek bu kuralın uygulanmaması söz konusu olamaz ${ }^{109}$. Ancak Honsell, şekil kuralı mutlak olarak geçerlilik taşımayıp, amaç şekli ise, böyle bir korunma taşınmaz satım sözleşmesinin her iki tarafça ifa edilmesinde olduğu gibi, artık gerekli değildir görüşündedir ${ }^{110}$. Yazar'a göre, her somut olayds menfaatler çatışması göz önünde tutularak bir karara vạılmalıdır ${ }^{111}{ }^{112}$.

${ }^{108}$ Canaris, s. 192 .
${ }^{109}$ Honsell, FS Mayer- Maly, s. 385 .
${ }^{110}$ Honsell, FS Mayer- Maly, s. 385 . Honsell'e göre, taşınmaz satım sözleşmelerinin resmi
şekilde yapılmasını düzenleyen İBK 216 , geçerlik şekli (Wirkform) değ il, amaç şeklidir
(Zweckform). Bu düzenlemede acele davranmadan koruma, ispat, sözleşmenin kurulması ve
tapu siciline tescil açısından hukuki açıklık söz konusudur (s. 377). Oysa, taraflar arasındaki
adalet, kamu düzeni karşısında daha güçlü bir argümandır. Aceleci davranmadan koruma her iki
tarafın ifası ile ortadan kalkar. Geriye açıklık ve hukuk güvenliğini gerçekleştirmek için kamu
düzeni kalır. Ancak bunun değeri, sözleşme adaletinin ihlal edilmesi esas alındığında o kadar
yüksek takdir edilemez. Dolayısıyla böyle bir durumda hukuken geçersiz olan bir sözleşme
fiilen geçerlidir (s. 377 ). Bu sebeple sözleşmenin şekli konusunda hakkın kötüye kullanılması
yasağına yer olmayıp, burada amaca uygun sinırlama yoluyla normun dar yonumlanması söz
konusudur (s. 379 ). İBK'nun 216 ve 11 . maddeleri, şekle aykın işlemin öncelikle henüz ifa
edilmediği durumlar için geçerli olacağı şeklinde yorumlanmalıdır (379). Hakkın kötüye
kullanılması yasağı ile düzeltme yerine amaca uygun sınırlama (teleologische Restriktion veya
Reduktion) geçer (s. 380 ).

Şekle aykınlık durumunda örtülüi boşluk bulunabileceği ve bu boşluğun hakkın kötüye kullanılması yasağı (MK 2/II) ile doldurulabileceği görüşü için, bkz., Serozan, Überwindung, s. 96 vd., 103, 104, 118 vd.

${ }^{111}$ Honsell ömek olarak, daha önce bahsettiğimiz AMK $\S 181$ 'deki vekilin kendi kendisiyle işlem yapma yasağında, Alman yargısının ve doktrininin bu kuralı menfaatler çatışmasını, -yani kanunun amacı olan temsil edileni korumak ile kamu düzeni menfaati arasındaki çatışmayıdikkate almaksızın uyguladığını ve daha sonra bu kararından vazgeçerek temsil edilenin korunması amacının ön planda tutulması gerektiğine karar verdiğini belirtmektedir (bkz., FS Mayer-Maly, s. 386).

${ }^{112}$ Şekle uyulmadan yapılmış sözleşmel erin hukuki sonuçlan konusundaki görüşler için bkz., Eren, s. 267 vd:; Serozan, Überwindung, s. 36 vd.; Altaş, Hüseyin: Şekle Aykınlığın Olumsuz Sonuçlanının Düzeltilmesi, Ankara 1998, s. 89 vd. 
3. Kıyas yasă̆ının bulunduğu hallerde amaca uygun sinirlama yapilamaz.

Kanunda kıyas yasağının bulunduğu hallerde (mesela kanun düzenlemeyi tiiketici bir şekilde yapmışsa), amaca uygun sınırlandırma yasağı da söz konusudur ${ }^{113}$. Ceza hukukunda kanunsuz suç ve ceza olmaz ilkesi gereği, kıyas yasağı bulunmaktadır, dolayısıyla amaca uygun sınırlandırma yasağı da söz konusudur.

4. "Kanunun ruhu ortadan kalktığında, kendisi de ortadan kalkar"114 ilkesine göre kanunu tam düzeltme amaca uygun sinırlama ile yaptlamaz.

Hukuk hayatındaki değişiklikler ve gelişmeler önceden mantıklı gelen normu, rasyonel olmayan bir duruma getirebilir. Ancak bu durumda da kanun koyucunun söz konusu normu kendisinin yürürlükten kaldırmasinı beklemek gerekir $^{115}$. Bu durumda hakim amaca uygun sınırlama yapamaz. Çünkü amaca uygun sinırlama mevcut norma bazı durumlarda sinurlama getirmek olup, düzenlemeyi tamamen yok saymak anlamina gelmez. Mevcut kanun ekonominin gereklerine uymuyorsa bu kanunu tamamen kaldırmak, hakimin değil, kanun koyucunun işidir. Aksi takdirde hukuk güvenliğinin ağır ölçüde zedelenmesi söz konusu olur ${ }^{116}$.

Ancak bu durumda da rasyonel olmayan normun dar yorumlanmasi ve kıyasen başka olaylara uygulanmaması gerekir. Bu normun uygulanmasının hakkın kötüye kullanılması oluşturduğu durumlarda düzeltilmesi imkanı ayrıca mevcuttur $^{117}$.

\section{Hakkın Kötüye Kullanılması Yasağı ile Amaca Uygun Sınırlama Arasındaki İliş̧i}

Amaca uygun sinırlama yapılabilmesi için somut olaya uygulanacak istisnanın kanunun değerleri ve amaçlarından çıkarılabilmesi gerekir. Buna karşılık hakkın kötüuye kullanılması yasağına başvurabilmek için, amaca uygun olarak yorumlanan normun somut olayın özel şartları gereği genelleştirilmiş amaca uygun sınırlama oluşturmaması, fakat adalet duygusunu büyük ölçüde zedeleyen mutlak haksız sonuçlara yol açması

\footnotetext{
${ }^{113}$ Larenz/Canaris, s. 211 ; Canaris, s. 193.

${ }^{114}$ Cessante ratione legis cessat ipsa lex. Glosse Non cohaeret, Digesta $35,1,72 \S 6$. Bu ilke hakkında bkz ., Larenz/Canaris, s. 171.

115 Kramer, Methodenlehre, s. 167.

116 Canaris, s. 189

${ }^{117}$ Bkz., Meier-Hayoz, s. 91.
} 
gerekir $^{118}$. Somut olaya uygulanması gereken norm kanunun amacı ve değerleri ile ters düşmemekle beraber, başından beri eksik veya zamanla tartışmalı hale gelmiş olduğu için tatmin edici değilse, hakimin kural olarak hukuk yaratma yetkisi yoktur. Ancak kanunun bu yetersizliği hakime bariz çarpıcı durumlarda MK 2/II' ye göre normu düzeltme yetkisi verir ${ }^{119}$.

Somut olaya ilişkin hakkaniyet düzeltmesi ile genelleştirilmiş amaca uygun sınırlama arasındaki sınır genellikle birbirinin içine girmektedir ${ }^{120}$. Uygulamada öncelikle tümevarımsal olarak (endüktif) hakkın kötïye kullanılması yasağına başvurulmakta, daha sonra genel indirgeme yoluna gidilmektedir.

Hakkın kötuiye kullanılması yasağı sadece, amaca uygun sınırlamanın mümkün olmadığı durumlarda, kanunun somut olaya uygulanması açık, kaba, göze batan adaletsizlikler ortaya çıkarıyorsa uygulanabilir ${ }^{121}$.

\section{Sonuç}

Kanunda bir düzenleme bulunmasina rağmen bu düzenlemenin onun maksadını aşarak çok geniş alanlan kapsaması ve somut olaya uygulandığı takdirde kanunun amacına aykırı sonuçlar ortaya çıkması durumunda, kanun boşluğu söz konusudur. Bu boşluk, kanunda mevcut düzenlemenin arkasında gizlendiği için örtülü boşluk olarak nitelendirilir. Ancak örtülü boşluğun da hakime kural koyma olanağı tanıyan gerçek boşluktan nitelik açıdan hiçbir farkı yoktur. Bu nedenle örtülü boşluklar gerçek olmayan boşluk olarak nitelendirilemez.

Örtülï boşluklar kanunun amacının gerektirdiği istisnanın eklenmesi veya geniş kanun lafzının somut olaya uygulanmaması yoluyla doldurulur. Bu yönteme amaca uygun sinırlama adı verilmektedir. Örtuilü boşluk durumunda hakim, MK 1'e göre boşlukları doldurur. Örtülü boşlukların doldurulması için, MK 2/II'de duizenlenen hakkın kötüye kullanılması yasağının daha ağır ve istisnai durumlarda uygulanabilen şartlarının gerçekleşmesi aranmaz. Ĕ̆ger

\footnotetext{
${ }^{118}$ Kramer, Methodenlehre, s. 168, 169; Meier-Hayoz, Schluss wort, s. 91.

${ }^{119}$ Meier-Hayoz, Schlusswort, s. 91.

${ }^{120}$ Kramer, Methodenlehre, s. 168, 169.

${ }^{121}$ Caroni, s. 152. Honsell'e göre hakkın kötüye kullanılması yasağ sadece bazı somut durumlarla sinırlıdır. Bu durumlar normun amaca uygun smırlama ile genelleştirilmesi için yeterli bir temelin söz konusu olmadı̆̆ı ve normun uygulanması tamamen haksız, adalet duygusunu büyük ölçüde zedeleyen sonuçlar doğuracaksa söz konusu olur. Bu nedenle şekle aykın bir işlemin ifa edilmesi durumunda hakkın kötüye kullanılması yasağına gerek yoktur (FS Mayer-Maly, s. 379).
} 
kanunda örtülï bir boşluk bulunmuyor, buna rağmen kanunun somut olaya uygulanması açıkça hakkın kötüye kullanılması niteliğindeyse bu takdirde MK 2/II'ye başvurularak istisnai durumlarda norm düzeltilmesi yapılabilir.

Örtülü boşluklar doldurulurken hakim kanunun amacını pozitif hukukun değerlerini göz önünde bulundurarak tespit eder ve bu amaca göre gerekli sunırlamayı yapar. Örtiilü boşlukların doldurulmasında amaçsal yorum mu yapıldığı, yoksa hakimin hukuk yaratmasının mı söz konusu olduğu her olayda kolayca belirlenemez. Bu konuda başvurulacak kriter sözcüklerden çıkarılacak anlamdır. Kanunun kelime anlamı, yani yorumu sonucunda ortaya çıkan sonuç, onun amacına ters düşüyorsa, amaca uygun sınırlandırma ile giderilecek örtülii bir boşluk söz konusudur. Kanunun amacı, sadece uygulanması söz konusu düzenlemenin amacı değil, kanunun bir bütün olarak değerlendirilmesi sonucunda ortaya çıkan amaçtır. 


\section{Bibliyografya}

Akipek, Jale G./ Akıntürk, Turgut: Türk Medeni Hukuku, Birinci Cilt, Başlangıç Hükümleri, Şahsın Hukuku, 3. bası, İstanbul 1998.

Akyol, Şener: Medeni Hukuka Giriş, İstanbul 1995.

Aral, Fahrettin: Borçlar Hukuku, Özel Borç İlişkileri, 3. Bas1, Ankara 2000

Ataay, Aytekin: Medeni Hukukun Genel Teorisi, İstanbul 1980.

Bucher, Eugen: Obligationenrecht, Besonderer Teil, 3. Aufl 1988.

Brandenburg, Hans-Friedrich: Die teleologische Reduktion, Grundlagen und Erscheinungsformen der auslegungsunterschreitenden Gesetzeseinschraenkung im Privatrecht, Göttingen 1983.

Bydlinski, Franz: Juristische Methodenlehre und Rechtsbegriff, 2. Aufl., Wien- New York 1991.

Canaris, Claus-Wilhelm: Die Feststellung von Lücken im Gesetz: eine metodologische Studie über Voraussetzungen und Grenzen der richterlichen Rechtsfortbildung praeter legem, Berlin 1964.

Caroni, Pio: Einleitungstitel des Zivilgesetzbuches, Basel und Frankfurt am Main 1996.

Diirr, David: Schweizerisches Zivilgesetzbuch, 3. Aufl., Einleitung, 1. Teilband, Art. 1-7, Zürich 1998.

Edis, Seyfullah: Medeni Hukuka Giriş ve Başlangıç Hükümleri, 3. bası Ankara 1987.

Engisch, Karl: Einführung in das juristische Denken, 9. Aufl., Stuttgart- Berlin- Köln 1997.

Eren, Fikret: Borçlar Hukuku, Genel Hükümler, C. 1, Gözden geçirilmiş 6. bası, İstanbul 1998.

Fellmann, Walter: Schweizerisches Zivilgesetzbuch, Das Obligationenrecht, Bd. VI, 2. Abteilung, Die einzelnen Vertragsverhaeltnisse, Der einfache Auftrag, Art. 394-406 OR, Bern 1992.

Fikentscher, Wolfgang: Methoden des Rechts in vergleichender Darstellung, Band. IV, Dogmatischer Teil, Tübingen 1977.

Gauch/Schluep/Schmid/Rey: Schweizerisches Obligationenrecht, Allgemeiner Teil, Bd. I, 7. Aufl., Zürich 1998.

Gauch, Peter: Der Fussballclub und sein Mietvertrag: Ein markanter Entscheid zur Übervorteilung, BGE 123 III 292, recht 1998, s. 55 vd.

Gauch, Peter: Art 404 OR- Sein Inhalt, seine Rechtfertigung und die Frage seines zwingenden Charakters, Urteilsanmerkung Zivilrechts BGE 115 II 464 vd., recht 1992, s. 9 vd. 
Gautschi, Geoerg: Berner . Kommentar, Kommentar zum schweizerischen Privatrecht, Band VI: Das obligationenrecht, 2. Abteilung: Die Einzelnenvertragsverhaeltnisse, 4. Teilband: Der einfache Auftrag, Art. 394-406 OR, 3. Aufl., Bern 1971.

Hatemi, Hüseyin: Medeni Hukuka Giriş, 2. bası, İstanbul 1999.

Haefelin, Ulrich: Zur Lückenfüllung im öffentlichen Recht, Festschrift zum 70. Geburstag von Hans Nef, Zürich 1981, s. 91 vd.

Hausheer, Heinz/ Jaun, Manuel: Die teleologische Reduktion und ihre Grenzen: zu BGE 123 III 445 ff. (keine gemeinsame elterliche Gewalt nach erfolgter Scheidung), ZBJV 1998, s. 501 vd.

Honsell, Heinrich: Teleologische Reduktion versus Rechtsmissbrauch, Festschrift für Theo Mayer-Maly zum 65. GeburstagWien- New York 1996, s. 269 vd.

İmre, Zahit: Medeni Hukuka Giriş, Temel Kavramlar, Medeni Kanunun Başlangıç Hükümleri ve Hakiki Şahıslar Hukuku, 3. Bası, İstanbul 1980.

Kramer, Ernst A.: Juristische Methodenlehre, Bern 1998.

Kramer, Ernst A.: Teleologische Reduktion- Plaedoyer für einen Akt methodentheoretischer Rezeption, Rechtsanwendung in Theorie und Praxis: Publikation uiber das Symposium zum 70. Geburtstag von Arthur MeierHayoz, Beiheft zur Zeitschrift für Schweizerisches Recht, Basel 1993, s. 65 vd.

Kramer, Ernst A.: Berner Kommentar, Das Obligationenrecht, Band VI, 1. Abteilung, 2. Teilband, Art. 19-22, Bern 1991.

Larenz, Karl: Methodenlehre der Rechtswissenschaft, 6. Aufl., München 1991.

Larenz, Karl/ Canaris, Claus-Wilhelm: Methodenlehre der Rechtswissenschaft, 3. Aufl., Berlin 1995.

Meier-Hayoz, Arthur: Berner Kommentar, Art. 1 ZGB, Bern 1962.

Meier-Hayoz, Arthur: Schlussworth, Rechtsanwendung in Theorie und Praxis: Publikation über das Symposium zum 70. Geburtstag von Arthur Meier-Hayoz, Beiheft zur Zeitschrift für Schweizerisches Recht, Basel 1993, s. 89 vd.

Merz, Hans: Berner Kommentar, Art. 2 ZGB, Bern 1962.

Merz, Hans: Neues $\mathrm{zu}$ den Methoden der Rechtsfindung, Rechtsanwendung in Theorie und Praxis: Publikation über das Symposium zum 70. Geburtstag von Arthur Meier-Hayoz, Beiheft zur Zeitschrift für Schweizerisches Recht, Basel 1993, s. 55 vd.

Neuner, Jörg: Die Rechtsfindung conra legem, Diss., München 1992. 
Oğuzman, Kemal/ Öz, Turgut: Borçlar Hukuku, Genel Hükümler, 3. Bas1, İstanbul 2000.

Öztan, Bilge/ Öztan, Fırat: İlga, Boşluk, Birlikte Yürürlükte Olma Kavramları Açısından Medeni Kanun'un 24/a-III'üncü Maddesi Karşısında Medeni Kanun'un 85/I'inci Maddesinin Durumu, Jale G. Akipek'e Armağan, Konya 1991, s. 245 vd.

Rhinow, René A.: Rechtsetzung und Methodik, Rechtstheoretischen Untersuchungen zum gegensetigen Verhaeltnis von Rechtsetzungen und Rechtsanwendung, Basel und Stuttgard 1979.

Riemer, Hans Michael: Berner Kommentar, Einleitungsartikel des schweizerischen Zivilgesetzbuches, (Art. 1-10), Eine Einführung, Bern 1987.

Serozan, Rona: Medeni Hukuka Giriş, İstanbul 1997.

Serozan, Rona: Die Überwindung der Rechtsfolgen des Formmangels im Rechtsgeschaeft nach deutschem, schweizerischem und türkischem Recht, Tübingen 1968.

Tandoğan, Haluk: Borçlar Hukuku, Özel Borç İlişkileri, Cilt: II, 3. Bas1, Ankara 1987.

Zeller, Ernst: Auslegung von Gesetz und Vertrag, Methodenlehre für juristische Praxis, Zürich 1989.

Ziegler, Antje: Die anfaengliche Unmöglichkeit der Leistung in der schweizerischen Lehre, Bern 1992. 1990.

Zippelius, Reinhold: Juristische Methodenlehre, 5. Aufl., Müchen

Zitelmann, Ernst: Lücken im Recht, Leipzig 1903. 


\section{Kisaltmalar}

AcP : Archiv für civilistische Praxis

AMK : Alman Medeni Kanunu

Art. : Artikel

Aufl. : Auflage

BATIDER : Banka ve Ticaret Hukuku Dergisi

BK : Türk Borçlar Kanunu

BGE : Entscheidungen des Bundesgesetz

bkz., : bakınız

C. : Cilt

FS : Festschrift

Hrsg. : Herausgeber

İBK : İsviçre Borçlar Kanunu

IMK : İsviçre Medeni Kanunu

MK : Türk Medeni Kanunu

N : Nummer

OR : Schweizerisches Obligationenrecht

s. $\quad$ : sayfa

SJZ : Schweizerische Juristen Zeitung

vd. : : ve devamı

YKD : Yargitay Kararları Dergisi

ZBJV : Zeitschrift des Bernischen Juristenvereins

ZGB : Schweizerisches Zivilgesetzbuch 